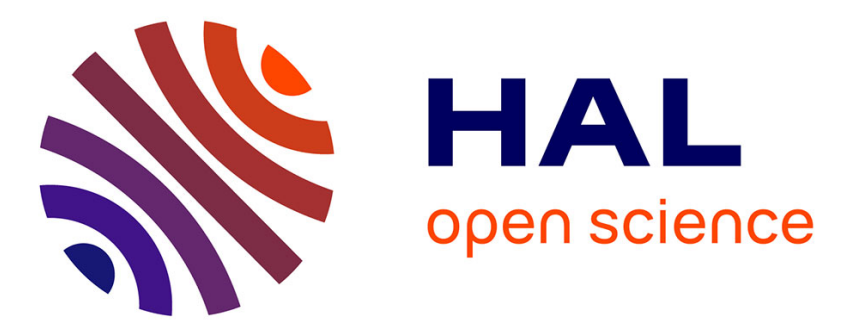

\title{
Mesoporous nickel-alumina catalysts derived from MIL-53(Al) metal-organic framework: A new promising path for synthesizing $\mathrm{CO} 2$ methanation catalysts
}

Leila Karam, Maria C Bacariza, José M Lopes, Carlos Henriques, Julien Reboul, Nissrine El Hassan, Pascale Massiani

\section{To cite this version:}

Leila Karam, Maria C Bacariza, José M Lopes, Carlos Henriques, Julien Reboul, et al.. Mesoporous nickel-alumina catalysts derived from MIL-53(Al) metal-organic framework: A new promising path for synthesizing CO2 methanation catalysts. Journal of CO2 Utilization, 2021. hal-03455763

\section{HAL Id: hal-03455763 https://hal.science/hal-03455763}

Submitted on 29 Nov 2021

HAL is a multi-disciplinary open access archive for the deposit and dissemination of scientific research documents, whether they are published or not. The documents may come from teaching and research institutions in France or abroad, or from public or private research centers.
L'archive ouverte pluridisciplinaire HAL, est destinée au dépôt et à la diffusion de documents scientifiques de niveau recherche, publiés ou non, émanant des établissements d'enseignement et de recherche français ou étrangers, des laboratoires publics ou privés. 


\title{
Mesoporous nickel-alumina catalysts derived from MIL-53(Al) metal-organic framework: A new promising path for synthesizing $\mathrm{CO}_{2}$ methanation catalysts
}

Leila Karamª, ${ }^{\mathrm{a} \mathrm{b}^{*}}$, Maria C. Bacariza ${ }^{\mathrm{c}}$, José M. Lopes ${ }^{\mathrm{c}}$, Carlos Henriques ${ }^{\mathrm{c}}$, Julien Reboul ${ }^{\mathrm{a}}$, Nissrine El Hassan ${ }^{\mathrm{b}}$, Pascale Massiani $^{\mathrm{a}}$

a Sorbonne Université, UPMC, Laboratoire de Réactivité de Surface, UMR CNRS 7197, 4 Place Jussieu, Paris, France.

${ }^{\mathrm{b}}$ University of Balamand, Department of Chemical Engineering, P.O. Box 33, Amioun El Koura, Lebanon.

${ }^{\mathrm{c}}$ Centro de Química Estrutural, Instituto Superior Técnico, Universidade de Lisboa, Av. Rovisco Pais, 1049-001 Lisboa, Portugal.

*Corresponding authors: julien.reboul@ sorbonne-universite.fr and leila.e.karam@gmail.com

\begin{abstract}
A new synthesis route for the preparation of highly efficient and stable porous Ni-based alumina catalysts for $\mathrm{CO}_{2}$ methanation is presented. It is based on the use of MIL-53(Al), an Al-containing metal-organic framework (MOF) with high surface area, as sacrificial support. A series of $\mathrm{Ni}_{-} \mathrm{Al}_{2} \mathrm{O}_{3}$ powder samples with Ni loadings ranging from 5 to $20 \mathrm{wt}$ \% was thus obtained. Their properties were thoroughly characterized by a set of complementary techniques including $\mathrm{N}_{2}$-sorption, $\mathrm{X}$-ray diffraction (XRD), thermo-gravimetric analysis (TGA), $\mathrm{CO}_{2}$ adsorption, temperature programmed reduction $\left(\mathrm{H}_{2}-\mathrm{TPR}\right)$ and transmission electron microscopy (TEM). After nickel impregnation and thermal assisted organic ligands elimination, the resulting $\mathrm{Ni}-\mathrm{Al}_{2} \mathrm{O}_{3}$ materials appear as interwoven alumina nanosheets in which $\mathrm{Ni}$ cations are intimately mixed forming $\mathrm{NiAl}_{2} \mathrm{O}_{4}$ spinel nanophases dispersed within amorphous alumina. This nanosheet morphology is preserved after the reduction of the $\mathrm{Ni}$ cations that leads to $\mathrm{Ni}^{0}-\mathrm{Al}_{2} \mathrm{O}_{3}$ catalysts composed of homogeneously and highly dispersed $\mathrm{Ni}^{0}$ nanoparticles, even at the highest $20 \mathrm{wt} \% \mathrm{Ni}$ content. As a result, the activity in $\mathrm{CO}_{2}$ methanation, evaluated between 250 to $450{ }^{\circ} \mathrm{C}$ under atmospheric pressure, using a constant gas hourly space velocity of $68900 \mathrm{~h}^{-1}$ and a molar reactant ratio $\mathrm{H}_{2} / \mathrm{CO}_{2}$ of 4 , increased proportionally with respect to the Ni loading. On the most active catalyst, the selectivity to $\mathrm{CH}_{4}$ was always excellent (between $96 \%$ and $100 \%)$ and the obtained $\mathrm{CH}_{4}$ yield $\left(\sim 70 \%\right.$ at $\left.300{ }^{\circ} \mathrm{C}\right)$ was about two times higher than on a commercial Ni-based $\mathrm{Al}_{2} \mathrm{O}_{3}$ catalyst containing $25 \mathrm{wt} \%$ of $\mathrm{Ni}$. The catalytic performances were also better than those of the already reported porous catalysts Ni/USY, Ni/SBA-15 as well as a Ni- $\mathrm{Al}_{2} \mathrm{O}_{3}$ synthesized by a EISA one-pot procedure, tested under the same reaction conditions for comparison. In this work the utilization of MIL-53(Al) as starting material for the synthesis of $\mathrm{Ni}-\mathrm{Al}_{2} \mathrm{O}_{3}$ catalysts was responsible for a peculiar improvement of the metallic dispersion due to the high surface area of this MOF and of the metal-support interaction likely due to the existence of remaining $\mathrm{NiAl}_{2} \mathrm{O}_{4}$ at the metal-support interface. Sintering and agglomeration (the main cause of deactivation) were therefore
\end{abstract}


limited, thus boosting the catalytic performance (activity, selectivity and stability). Keywords: $\mathrm{CO}_{2}$ methanation; Nickel nanoparticles; MIL-53(Al); mesoporous $\mathrm{Al}_{2} \mathrm{O}_{3}$; metal-support interaction

\section{Introduction}

Power-to-gas strategies that foresee a more efficient use of renewable sources for the production of energy have been widely explored in the recent years [1-5]. One of the promising approaches consists in storing the electrical surplus issued from wind or solar technologies via a chemical route which involves reacting renewable $\mathrm{H}_{2}$ (electrically produced by water splitting) with $\mathrm{CO}_{2}$ (a greenhouse gas) to produce methane $[2-4,6]$. The obtained synthetic natural gas (SNG) can then be consumed directly as an energy feedstock or be used as an energy storage system (able to give back $\mathrm{H}_{2}$ ). An advantage of this chemical storage system is that methane is safer than $\mathrm{H}_{2}$ and distributable through the existing natural gas grid. Moreover, such process, leads to $\mathrm{CO}_{2}$ emissions mitigation and to the management of the unpredictable renewable sources.

$\mathrm{CO}_{2}$ methanation is thermodynamically the most favourable route for carbon dioxide hydrogenation [7]. To ensure high $\mathrm{CH}_{4}$ selectivity, a medium temperature is needed (between 200 and $400{ }^{\circ} \mathrm{C}$ ) to avoid side reactions, especially the reverse water gas shift reaction that occurs above $450^{\circ} \mathrm{C}$ and produces $\mathrm{CO}$ [8]. Nevertheless, $\mathrm{CO}_{2}$ methanation is also a kinetically limited eight-electron process [9], therefore a very active catalyst is mandatory, at such low temperatures, to achieve acceptable rates of reductive hydrogenation of $\mathrm{CO}_{2}$ into $\mathrm{CH}_{4}$. Amongst the recent studies on $\mathrm{CO}_{2}$ methanation catalysts, many have been dedicated to nickel (a transition metal) based on its promising activity, selectivity and comparatively low price compared to noble metals. Attempts were done to enhance the catalysts performances by playing on the nickel dispersion [9], increasing its interaction and/or electron transfer with the support [10], or introducing defect (anchoring) sites on the support [11]. Different types of supports were also tested, including porous/non-porous alumina $\left(\mathrm{Al}_{2} \mathrm{O}_{3}\right)$ (which is robust, thermally stable, favourable surface properties), ceria $\left(\mathrm{CeO}_{2}\right)$ and zirconia $\left(\mathrm{ZrO}_{2}\right)$ (whose redox properties increases oxygen vacancies, it also has good thermal stability), hydrotalcites (owing to its capacity to reduce $\mathrm{Ni}$ species and to host high $\mathrm{Ni}$ amount with good dispersion), zeolites (some of them present chemically active nanostructures and space for sorption properties enhancement), $\mathrm{MgO}$ (owing to its basicity) and natural clays (they possess environmental compatibility, low cost, reusability, and operational simplicity) [12-15]. However, $\mathrm{CO}_{2}$ conversions often remained unsatisfactory in the conditions applied and temperature increase did not provide any improvement because of affecting negatively the selectivity to methane and also the efficiency of the catalyst due to nickel sintering and formation of coke deposits. In order to limit such drawbacks, a positive effect of using a support with 
regular porosity, high surface area and wide pore diameter was demonstrated [16,17]. Moreover, among the tested supports, alumina (mainly $\mathrm{\gamma}-\mathrm{Al}_{2} \mathrm{O}_{3}$ ) was the most widely used due its easy access, developed surface area and known surface acid-base properties that contribute to $\mathrm{CO}_{2}$ adsorption/activation [18].

Recently, we reported the preparation of very efficient mesoporous $\mathrm{Ni} /$ alumina catalysts prepared by one-pot able to resist the high temperatures imposed by thermodynamics during dry reforming of methane (DRM) reaction [19], whose conditions are much harsher than those for $\mathrm{CO}_{2}$ methanation. These samples modified with different amount of magnesium booster showed indeed excellent performances in $\mathrm{CO}_{2}$ methanation as well [20]. For further development in the alumina catalyst system, a more innovative synthesis route was adapted. This process consisted of using an aluminium-based Metal-Organic Frameworks (MOF) as sacrificial parent support capable of intimately mixing nickel and aluminium cations. MOF are indeed excellent candidates for this purpose due to their opened porosity and very high surface area $\left(1000-3000 \mathrm{~m}^{2} \cdot \mathrm{g}^{-1}\right)$ that can help in dispersing and stabilizing guest metal cations in close proximity to the framework inorganic cornerstones. Noteworthy, the use of MOFs, which are hybrid materials built from a coordination of metal ions (clusters) with organic ligands (linkers), as catalyst supports under gas phase conditions is still in its infancy. Certain catalysts made of MOF hosting platinum, nickel or ruthenium metal nanophases were indeed recently reported [21] leading to performances that overcame those obtained on conventional oxide supports. Nevertheless, a drawback of MOFs is their well-known thermal instability due to linkers degradation at the temperatures at which catalytic reactions usually take place. Thus, an alternative is to use MOFs as a precursor, giving after linker degradation, a stable carbonaceous or purely inorganic material depending on the initial MOF composition and thermal treatment adopted. This route was recently applied to prepare $\mathrm{Ru} / \mathrm{ZrO}_{2}$ catalysts with highly dispersed $\mathrm{Ru}$ (nanoparticles size of 2-5 nm) [22] or to obtain Co-containing porous carbons in which sintering of the Co nanoparticles was prevented owing to their separation by the graphite-like carbon sheets [23]. We also recently used this approach to develop new performing porous Ni/alumina DRM catalyst containing 5 wt.\% of Ni, [24,25] synthesized from MIL-53(Al), a MOF composed of aluminium hydroxyl chains connected to each other by terephthalate ligands [24]. This MOF was first impregnated with a nickel precursor solution to set the metal cations in proximity with the $\mathrm{Al}$ nods, then a calcination step was carried out to eliminate the organic linkers resulting in nickel aluminate nanophases homogeneously dispersed within an amorphous alumina. This mixed metal oxide phase is believed to be the key intermediate responsible for the remarkably high dispersion and stability of the nickel active phase formed after the final reduction step. 
This MIL-53(Al)-derived route is extended in the present work to prepare a series of novel porous Ni$\mathrm{Al}_{2} \mathrm{O}_{3}$ materials with increasing $\mathrm{Ni}$ contents (from 5 to $20 \mathrm{wt} . \%$ ) and test them for the first time in $\mathrm{CO}_{2}$ methanation. A complementary set of physicochemical techniques (XRF, XRD, N2-sorption, TGA, $\mathrm{CO}_{2}$ adsorption, $\mathrm{H}_{2}$-TPR and HR-TEM) is used to identify the impact of the increasing Ni content on the structural, textural and surface properties of the materials. The nickel state, location and dispersion are also carefully analysed. Finally, the performances are tested in $\mathrm{CO}_{2}$ methanation and discussed in view of the materials properties. For the sake of completion, the physicochemical characteristics and performances of the new MOF-derived materials are also compared to those of more conventional catalysts containing $15 \mathrm{wt} \% \mathrm{Ni}$ supported on ordered porous oxides (mesoporous Ni-alumina, microporous $\mathrm{Ni} /$ zeolite and mesoporous $\mathrm{Ni} / \mathrm{SBA}-15)$ and to a commercial Ni-alumina catalyst containing a higher Ni loading (25 wt.\%).

\section{Experimental}

\subsection{Materials preparation}

A parent MIL-53(Al) sample was synthesized according to a known procedure [26]. It consisted of mixing $1.21 \mathrm{~g}$ of $\mathrm{AlCl}_{3} \cdot 6 \mathrm{H}_{2} \mathrm{O}$ and $0.42 \mathrm{~g}$ of benzene-1,4-di-carboxylic acid with $3 \mathrm{ml}$ water and $5 \mathrm{ml}$ of dimethylformamide (DMF), then transferring the mixture into a $50 \mathrm{ml}$ reactor and heating it in a microwave oven for 30 minutes at $125{ }^{\circ} \mathrm{C}$ under a power of $200 \mathrm{~W}$. The resultant precipitate was recovered by centrifugation, washed six times in $10 \mathrm{~mL}$ DMF solution and in $10 \mathrm{~mL}$ deionized water to ensure full removal of unwanted residues (unreacted terephthalic acid, aluminium salt and solvents). After centrifugation, the white powder was dried for $24 \mathrm{~h}$ at $80{ }^{\circ} \mathrm{C}$ and heated in air at $220{ }^{\circ} \mathrm{C}$ for $72 \mathrm{~h}$ to obtain the activated (adsorbate free) sample, denoted MIL-53.

Nickel impregnation was then performed by adding dropwise a $\mathrm{Ni}\left(\mathrm{NO}_{3}\right)_{2} \cdot 6 \mathrm{H}_{2} \mathrm{O}$ aqueous solution with a volume chosen similar to the MIL-53 pore volume (as determined from $\mathrm{N}_{2}$-sorption, see below) and a nickel concentration corresponding to a $\mathrm{Ni}$ content (in the reduced catalyst) of either 5, 15 or 20 wt.\%. These impregnated samples were dried at room temperature for $24 \mathrm{~h}$, then treated in static air for $5 \mathrm{~h}$ at $500{ }^{\circ} \mathrm{C}$ (thin bed conditions, heating rate of $0.5^{\circ} \mathrm{C} . \mathrm{min}^{-1}$ ) to decompose the organic linkers and obtain the series of calcined $\mathbf{N i}_{\mathbf{x}}-\mathbf{A l}_{\mathbf{2}} \mathbf{O}_{3}$-MIL-53 materials (where $\mathrm{x}$ is the $\mathrm{Ni}$ wt.\%). Below is a brief schematic illustrating the MOF based catalyst preparation (Scheme 1). 

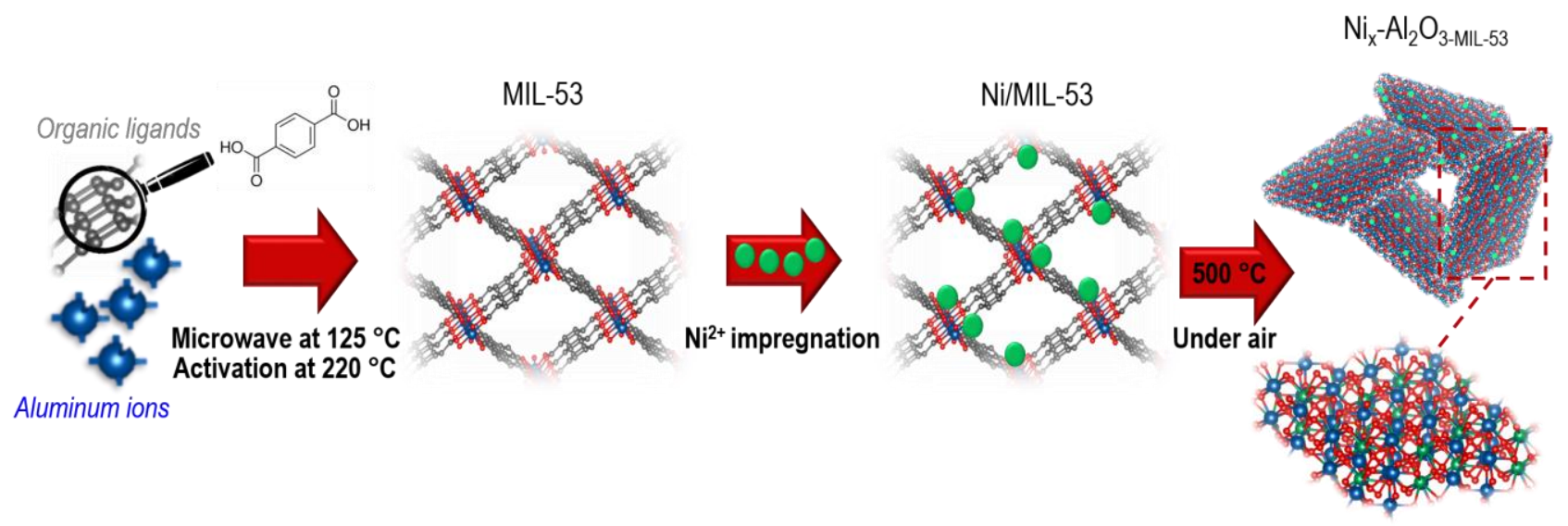

Scheme 1: Schematic summarizing the MOF-based preparation route of the Ni-alumina catalyst $\left(\mathrm{Ni}_{\mathrm{x}^{-}}\right.$

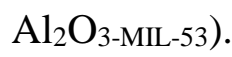

For comparison purposes, an ordered mesoporous Ni15-Al_2O3-OP material containing 15 wt.\% of nickel was also synthetized, following our recently described evaporation induced self-assembly (EISA) one-pot method [19], and a commercial Ni25/ $\boldsymbol{\gamma}-\mathbf{A l}_{2} \mathbf{O}_{3}$ catalyst containing 25 wt. \% Ni (Evonik) was used. Moreover, two silica-based catalysts referred as Ni15/USY and Ni15/SBA-15 were prepared by incipient wetness impregnation with $15 \mathrm{wt}$ \% nickel of a Cs-USY zeolite $\left(\mathrm{Si} / \mathrm{Al}_{\text {global }}\right.$ ratio $\left.=38\right)$ $[27,28]$ and of a commercial SBA-15 [29], respectively. Part of each sample was submitted to reduction in a flow of $5 \% \mathrm{H}_{2} / \mathrm{Ar}\left(25 \mathrm{~mL} \cdot \mathrm{min}^{-1}\right)$ in the conditions of $\mathrm{H}_{2}$-TPR measurement to prepare the reduced catalysts. The temperatures of reduction were chosen according to the $\mathrm{H}_{2}$-TPR profiles (Fig. 5A) and were as follows; $650^{\circ} \mathrm{C}\left(\mathrm{Ni}^{0}{ }_{15} / \mathrm{SBA}-15\right), 700^{\circ} \mathrm{C}\left(\mathrm{Ni}^{0}{ }_{15} / \mathrm{USY}\right)$ and $800^{\circ} \mathrm{C}\left(\mathrm{Ni}^{0}{ }_{\mathrm{x}}-\mathrm{Al}_{2} \mathrm{O}_{3-\mathrm{MIL} 53}, \mathrm{Ni}^{0}{ }_{15}-\mathrm{Al}_{2} \mathrm{O}_{3}\right.$ OP and $\left.\mathrm{Ni}_{25}{ }_{25} / \gamma-\mathrm{Al}_{2} \mathrm{O}_{3}\right)$.

\subsection{Materials characterization}

X-Ray Fluorescence (XRF) carried out on a XEPOS spectrometer (Spectro Ametek) was used to measure and validate the Ni contents using a MicroPowder method and a calibration curve previously established from $\mathrm{NiO}$ and alumina mixtures with known chemical compositions.

Thermogravimetric (TGA) analyses were performed on a Setsys Evolution TGA (Setaram instruments). The samples were saturated with water prior experiment, then the temperature was raised from room temperature till $400{ }^{\circ} \mathrm{C}$ (heating rate of $\left.10^{\circ} \mathrm{C} / \mathrm{min}\right)$ under air flow $(30 \mathrm{~mL} / \mathrm{min})$. Water desorption, occurring in this temperature range and giving an endothermic peak as confirmed by DSC, was used to determine the $\mathrm{h}$ index indicative of the water affinity with the sample $[27,30]$ and calculated as the ratio between the mass losses at $\sim 150{ }^{\circ} \mathrm{C}$ (weakly interacting water molecules) and $400{ }^{\circ} \mathrm{C}$ (strongly interacting water molecules). 
Powder XRD patterns were obtained on a Bruker AXS Advance D8 diffractometer equipped with a 1D detector (SSD 160). The $\mathrm{Cu} \mathrm{K \alpha}$ radiation was used and the equipment was operated at $40 \mathrm{kV}$ and $40 \mathrm{~mA}$. The scanning range was set from $5^{\circ}$ to $80^{\circ}(2 \theta)$, with a step size of $0.03^{\circ} / 2 \mathrm{~s}$. The Scherer equation was applied to evaluate the average size $\left(\mathrm{D}\right.$ in $\mathrm{nm}$ ) of crystal domains $\left(\mathrm{NiO}\right.$ or $\mathrm{NiAl}_{2} \mathrm{O}_{4}$ before reduction and $\mathrm{Ni}^{0}$ after reduction), expressed as $\mathrm{D}=\mathrm{K} \lambda / \beta \cos \theta$ where $\mathrm{K}=0.9$ is a constant, $\lambda$ is the wavelength of the incident X-ray beam, $\beta$ is the full width at half maximum (FWHM) of the diffraction peaks, and $\theta$ corresponds to peak position usually taken in our study at $2 \theta=45^{\circ}$ for $\mathrm{NiO}$ or $\mathrm{NiAl}_{2} \mathrm{O}_{4}$, and $50.9^{\circ}$ for $\mathrm{Ni}^{0}$.

$\mathrm{N}_{2}$ adsorption-desorption isotherms were recorded at $-196{ }^{\circ} \mathrm{C}$ using a BELsorp-max (MicrotracBEL) apparatus. Each sample was firstly degassed under vacuum for $2 \mathrm{~h}$ at $250{ }^{\circ} \mathrm{C}\left(7 \mathrm{~h}\right.$ at $200{ }^{\circ} \mathrm{C}$ for MIL53(Al)), then placed at liquid nitrogen temperature afterwards the $\mathrm{N}_{2}$-isotherm was plotted. Specific surface areas were calculated from the BET equation at relative pressures between 0.05 and 0.25 . The corresponding single point pore volume was obtained from the sorption branch at a relative pressure of 0.99 .

$\mathrm{CO}_{2}$ isotherms were collected at $0{ }^{\circ} \mathrm{C}$ on an Autosorb iQ equipment from Quantachrome. Before adsorption, the samples were degassed under vacuum at $90{ }^{\circ} \mathrm{C}$ for $1 \mathrm{~h}$ and then at $350{ }^{\circ} \mathrm{C}$ for $4 \mathrm{~h}$. Experiments were run using the same conditions applied in previous works [27,31,32].

$\mathrm{H}_{2}$-TPR studies were performed in a Micromeritics AutoChem II instrument. The samples ( 100 mg) were first pre-treated at $250{ }^{\circ} \mathrm{C}$ under argon flow, then cooled down to room temperature, and reduction was carried out in a $5 \% \mathrm{H}_{2} / \mathrm{Ar}$ flow $\left(25 \mathrm{~mL} \cdot \mathrm{min}^{-1}\right)$ with a temperature increase from room temperature to $900{ }^{\circ} \mathrm{C}$ (heating rate of $10^{\circ} \mathrm{C} / \mathrm{min}$ ). A TCD detector was used to quantify the hydrogen consumption. Before reaching it, the outlet gas was passed in a cold trap $\left(\mathrm{CO}_{2}\right.$ ice temperature $)$ to remove the water molecules formed during reduction $\left(\mathrm{H}_{2(\mathrm{~g})}+\mathrm{NiO}_{(\mathrm{s})} \rightarrow \mathrm{Ni}^{0}{ }_{(\mathrm{s})}+\mathrm{H}_{2} \mathrm{O}_{(\mathrm{g})}\right)$.

High-resolution transmission electron microscopy (HRTEM) images were taken on a JEOL-JEM 200 electron microscope operating at $200 \mathrm{keV}$ ( $\mathrm{LaB}_{6}$ gun). Before observations, the powders were suspended in ethanol for few minutes under ultrasound vibration, and then deposited on a copper grid coated with carbon membrane (microtomy). The "Comptage de Particules" software available at LRS was considered to estimate the average particle size of nickel $\left(\mathrm{Ni}^{0}\right)$ particles. To do so, around 500 particles present in the grains were taken into consideration where the channels are oriented parallel to the electron beam.

\subsection{Catalytic tests}


Catalytic tests were conducted in a fixed-bed reactor at atmospheric pressure. Prior to reaction, all samples $(200 \mathrm{mg})$ were in-situ reduced under an $80 \% \mathrm{H}_{2} / \mathrm{N}_{2}$ flow $\left(250 \mathrm{~mL} \cdot \mathrm{min}^{-1}\right)$ at a heating rate of 5 ${ }^{\circ} \mathrm{C} . \mathrm{min}^{-1}$ from room temperature till a selected maximum temperature that was maintained for $1 \mathrm{~h}$. This temperature was chosen from $\mathrm{H}_{2}$-TPR profiles as to allow the complete nickel reduction species into metallic $\mathrm{Ni}^{0}$. The value of the temperature was equal to $650{ }^{\circ} \mathrm{C}$ for $\mathrm{Ni}_{15} / \mathrm{SBA}-15,700{ }^{\circ} \mathrm{C}$ for $\mathrm{Ni}_{15} / \mathrm{USY}$ and $800{ }^{\circ} \mathrm{C}$ for $\mathrm{Ni}_{\mathrm{x}}-\mathrm{Al}_{2} \mathrm{O}_{3-\mathrm{MIL}-53}, \mathrm{Ni}_{15}-\mathrm{Al}_{2} \mathrm{O}_{3-\mathrm{OP}}$ and commercial $\mathrm{Ni}_{25} / \gamma-\mathrm{Al}_{2} \mathrm{O}_{3}$. The reactants were next introduced into the reactor at a molar ratio of $\mathrm{H}_{2}: \mathrm{CO}_{2}: \mathrm{N}_{2}=36: 9: 10$ (total flow of $287 \mathrm{~mL} \cdot \mathrm{min}^{-1}$ ) and the $\mathrm{CO}_{2}$ methanation reaction was performed stepwise, at temperatures ranging from 250 to $450{ }^{\circ} \mathrm{C}$. The global inlet volumetric flow rate, leading to a gas hourly space velocity (GHSV) of $68900 \mathrm{~h}^{-1}$, was chosen based on previous studies which proved that these experimental conditions avoid external mass diffusion limitations.

Air Liquide supplied all gases, with purities $\geq 99.9990 \%$. The reactor effluent was analysed using three Guardian ${ }^{\circledR}$ NG infrared detectors (Edinburgh Sensors) for $\mathrm{CO}_{2}, \mathrm{CH}_{4}$ and $\mathrm{CO}$. The outlet flow was simultaneously measured to estimate the variation of the number of moles consecutive to the Sabatier reaction $\left(\mathrm{CO}_{2}+4 \mathrm{H}_{2} \rightarrow \mathrm{CH}_{4}+2 \mathrm{H}_{2} \mathrm{O}\right)$ and take it into account in the determination of the catalytic performances expressed as $\mathrm{CO}_{2}$ conversion $\left(\mathrm{X}_{\mathrm{CO} 2}=\right.$ mol $\left._{\mathrm{CO} 2 \text {-transformed }} / \mathrm{mol}_{\mathrm{CO} 2 \text {-inlet }}\right)$ and selectivity to $\mathrm{CH}_{4}$ $\left(\mathrm{S}_{\mathrm{CH} 4}=\right.$ mol $_{\mathrm{CH} 4 \text {-produced }} /$ mol $\left._{\mathrm{CO} 2 \text {-converted }}\right)$. Carbon balances were systematically evaluated to verify the absence of by-products in the effluents where only $\mathrm{CH}_{4}$ and $\mathrm{CO}$ were detected as products. In addition, turnover frequency numbers (TOF) were calculated using the equation: $\mathrm{TOF}\left(\mathrm{s}^{-1}\right)=\mathrm{X} \cdot \mathrm{F}_{\mathrm{Ae}} \cdot \mathrm{Mw}_{\mathrm{Ni}}$ $(1 / \mathrm{W}) \cdot\left(1 / \mathrm{D}_{\mathrm{Ni}}\right) \cdot\left(1 / \mathrm{X}_{\mathrm{Ni}}\right)$, where $\mathrm{X}$ is the $\mathrm{CO}_{2}$ conversion, $\mathrm{F}_{\mathrm{Ae}}$ is the inlet molar flow of $\mathrm{CO}_{2}\left(\operatorname{mol}_{\mathrm{CO}_{2}}\right.$ inlet $\left.\cdot \mathrm{min}^{-1}\right), \mathrm{W}$ is the mass of catalyst $\left(\mathrm{g}_{\text {catalyst }}\right.$ ), $\mathrm{D}_{\mathrm{Ni}}$ is the nickel dispersion and $\mathrm{X}_{\mathrm{Ni}}$ is the nickel content $\left(\mathrm{g}_{\mathrm{Ni}} \cdot \mathrm{g}_{\mathrm{cat}}{ }^{-1}\right)[33]$.

Finally, and with the aim of comparing the results of the most outstanding catalyst from this work with literature, average $\mathrm{CO}_{2}$ reaction rates (r) were determined by Equation 1, with $\mathrm{F}_{\mathrm{CO} 2 \text {.inlet }}\left(\right.$ molcO2.s $^{-1}$ ) corresponds to the inlet molar flow of $\mathrm{CO}_{2}$ and $\mathrm{W}(\mathrm{g})$ to the total mass of catalyst, assuming a CSTR model:

$$
\mathrm{r}\left(\mathrm{mol} \mathrm{CO} 2 \cdot \mathrm{s}^{-1} \cdot \mathrm{g}^{-1}\right)=\mathrm{CO}_{2} \text { conversion } \cdot \mathrm{F}_{\mathrm{CO}_{2} \text {,inlet }}(1 / \mathrm{W}) \quad(\text { Equation } 1)
$$

\section{Results and discussion}

\subsection{Textural and structural properties of the calcined samples}


The first columns of Table 1 list the labels and Ni contents measured by XRF for the series of prepared materials. The Table also details their mean pores volumes (micropores and mesopores) and surface area deduced from $\mathrm{N}_{2}$ sorption measurements carried out on calcined and reduced samples. The corresponding isotherms are shown in Figure 1.

Table 1. Textural and surface properties of the prepared samples

\begin{tabular}{|c|c|c|c|c|c|c|c|}
\hline \multirow{2}{*}{\multicolumn{2}{|c|}{ Materials }} & \multirow{2}{*}{$\begin{array}{c}\mathrm{Ni} \\
\text { content }^{\mathrm{a}} \\
(\mathrm{wt} . \%)\end{array}$} & \multicolumn{3}{|c|}{ Textural properties $^{b}$} & \multicolumn{2}{|c|}{ Surface properties } \\
\hline & & & & & & & Amount of \\
\hline \multirow{6}{*}{$\begin{array}{c}\text { Alumina- } \\
\text { based }\end{array}$} & MIL-53 & - & 0.40 & 0.40 & 1130 & - & - \\
\hline & $\mathrm{Ni}_{5}-\mathrm{Al}_{2} \mathrm{O}_{3-\mathrm{MIL}-53}$ & 5.1 & $0.05(<0.01)$ & $0.97(0.85)$ & $223(225)$ & 0.64 & \\
\hline & $\mathrm{Ni}_{15}-\mathrm{Al}_{2} \mathrm{O}_{3-\mathrm{MIL}-53}$ & 14.7 & $<0.01$ & $1.09(0.96)$ & $251(250)$ & 0.60 & $8.2(17.1)$ \\
\hline & $\mathrm{Ni}_{20}-\mathrm{Al}_{2} \mathrm{O}_{3-\mathrm{MIL}-53}$ & 19.5 & $<0.01$ & $1.05(0.71)$ & $245(175)$ & 0.58 & $16(28)$ \\
\hline & $\mathrm{Ni}_{15}-\mathrm{Al}_{2} \mathrm{O}_{3-\mathrm{OP}}$ & 14.2 & $<0.01$ & $0.13(0.11)$ & $60(44)$ & 0.38 & $5.5(9.6)$ \\
\hline & $\mathrm{Ni}_{25} / \gamma-\mathrm{Al}_{2} \mathrm{O}_{3} *$ & 25 & $<0.01$ & $0.45(0.42)$ & $229(103)$ & 0.77 & $15.4(24.4)$ \\
\hline \multirow{2}{*}{$\begin{array}{l}\text { Silica- } \\
\text { based }\end{array}$} & $\mathrm{Ni}_{15} / \mathrm{USY}$ & 14.5 & $0.16(<0.01)$ & $0.20(0.25)$ & $259(261)$ & 0.87 & $14(23.3)$ \\
\hline & $\mathrm{Ni}_{15} / \mathrm{SBA}-15$ & 14.5 & $0.11(<0.01)$ & $0.66(0.62)$ & $487(422)$ & 0.98 & $9.7(21.1)$ \\
\hline
\end{tabular}

a: Ni content in the calcined dehydrated materials as estimated by XRF

b: as estimated from $\mathrm{N}_{2}$ adsorption measurements for the calcined and reduced (in brackets) samples

c: ratio of the water weight losses during TG analysis after heating at $150{ }^{\circ} \mathrm{C}$ and $400{ }^{\circ} \mathrm{C}$, respectively

d: amount of $\mathrm{CO}_{2}$ adsorbed at $0{ }^{\circ} \mathrm{C}$ at $\mathrm{P} / \mathrm{P}_{0}$ partial pressures of 0.01 and 0.3 (in brackets)

*: Commercial sample. 


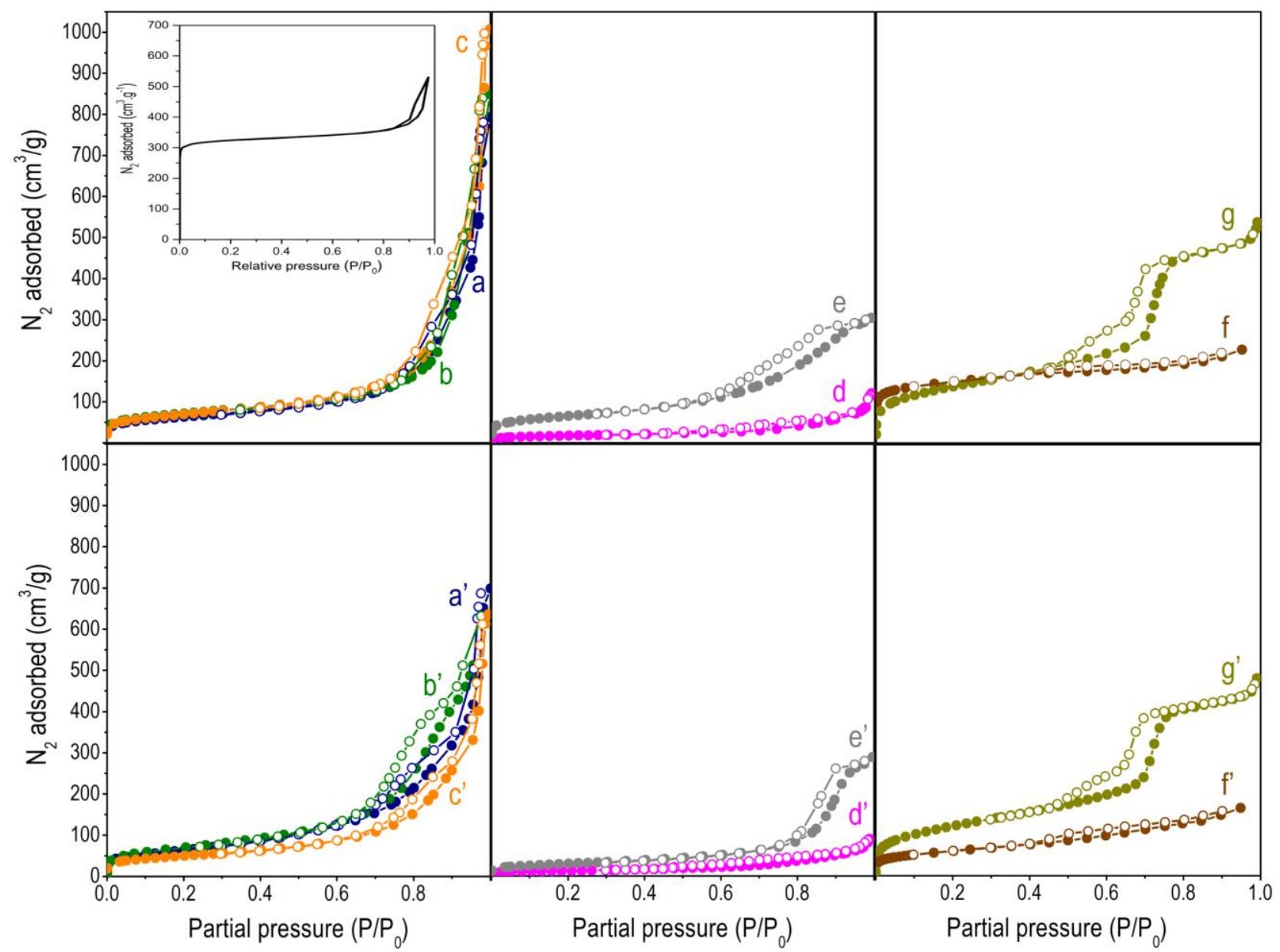

Figure 1: $\mathrm{N}_{2}$ physisorption isotherms of (a-g) calcined and ( $\left.a^{\prime}-g^{\prime}\right)$ reduced samples: (a, $\left.a^{\prime}\right) \mathrm{Ni}_{5}-\mathrm{Al}_{2} \mathrm{O}_{3-\mathrm{MIL}-53}$, (b,b') $\mathrm{Ni}_{15}-\mathrm{Al}_{2} \mathrm{O}_{3}{ }^{-M I L-53,},\left(c, c^{\prime}\right) \mathrm{Ni}_{20}-\mathrm{Al}_{2} \mathrm{O}_{3-\mathrm{MLL}-53}$, (d,d') $\mathrm{Ni}_{15}-\mathrm{Al}_{2} \mathrm{O}_{3-\mathrm{OP}}$, (e,e') $\mathrm{Ni}_{25} / \gamma-\mathrm{Al}_{2} \mathrm{O}_{3}$, (f,f') $\mathrm{Ni}_{15} / \mathrm{USY}$ and $\left(g, g^{\prime}\right) N i_{15} / S B A-15$. The inset shows the isotherm of the parent MIL-53 support.

As commonly expected for a MOF material, the parent activated MIL-53 exhibits a type I isotherm characteristic of a microporous material and a very high surface area, above $1100 \mathrm{~m}^{2} \cdot \mathrm{g}^{-1}$ (inset in Fig. 1 and Table 1). Its impregnation with $5 \mathrm{wt} \% \mathrm{Ni}$ followed by linkers decomposition results in the loss of the micropores and in a decrease of the specific area by a factor of about 5 , as already discussed in more details in our recent paper [24]. Nevertheless, the total pore volume is simultaneously increased by $20 \%$ (Table 1) due to the formation of external meso/macro pores between the aggregated nanocrystals. This is attested by the type IV isotherms whose slit-type hysteresis loop in the $0.75-0.9$ relative pressures range and marked step at relative pressures above $\mathrm{P} / \mathrm{P}_{0}=0.9$ are typical of a layered mesoporous material (Fig. 1a). Increasing the Ni amount from 5 wt.\% to 15 wt.\% (Fig. 1b) and then to $20 \mathrm{wt} . \%$ (Fig. 1c) does not alter the shape of the isotherm nor the surface area $\left(220-250 \mathrm{~m}^{2} \cdot \mathrm{g}^{-1}\right)$ and total pores volumes $\left(0.97-1.09 \mathrm{~cm}^{3} \cdot \mathrm{g}^{-1}\right)$ that are close in all calcined $\mathrm{Ni}_{\mathrm{x}}-\mathrm{Al}_{2} \mathrm{O}_{3-\mathrm{MIL}}$ materials (Table 1) and higher than in the comparative ordered mesoporous $\mathrm{Ni}_{15}-\mathrm{Al}_{2} \mathrm{O}_{3}$-OP sample obtained by one-pot- 
EISA method (Fig. 1d). For the latter, it is worth noting that its porous properties $\left(60 \mathrm{~m}^{2} \cdot \mathrm{g}^{-1}, 0.13\right.$ $\mathrm{cm}^{3} \cdot \mathrm{g}^{-1}$ ) are significantly lower than those reported in our previous study for a one-pot-EISA synthesized sample prepared under the same conditions [19,25], but this is most probably due to the 3 times higher Ni content used here, that changed the Ni precursor concentration in the synthesis medium (change of $\mathrm{pH}$ ), potentially affecting the structuring process during formation of the material. The total

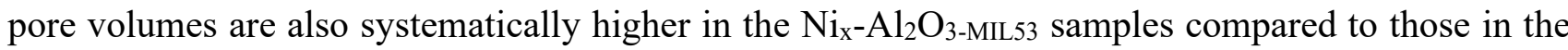
silica-based references (Table 1), which are as expected either microporous ( $\mathrm{Ni}_{15} /$ USY zeolite, type I isotherm, Fig. 1f) or mesoporous with a narrow distribution of large mesopores ( $\mathrm{Ni}_{15} / \mathrm{SBA}-15$, type IV isotherm with a $\mathrm{H} 1$ type hysteresis loop at $\mathrm{P} / \mathrm{P}_{0}$ between 0.75 and 1, Fig. 1g).

The existence of an intergranular porosity in all the samples of the $\mathrm{Ni}_{\mathrm{X}}-\mathrm{Al}_{2} \mathrm{O}_{3}-\mathrm{MIL}-53$ series is confirmed by transmission electron microscopy, as shown by the representative HR-TEM images of calcined $\mathrm{Ni}_{5}$ $\mathrm{Al}_{2} \mathrm{O}_{3-\mathrm{MIL}-53}$ (Fig. 2A) and $\mathrm{Ni}_{15}-\mathrm{Al}_{2} \mathrm{O}_{3-\mathrm{MIL}-53}$ (Fig. 2B). Whatever the Ni content, the sample appears as randomly interwoven nanosheets with ill-defined shapes and size of approximately 20-50 nm in length (see insets in Fig. 2A and 2B). Although $\mathrm{Ni}$ is known to be present (because being introduced by incipient wetness impregnation), the images do not permit to detect any nickel-based particles (expected to appear darker than the support, if they exist), which suggests an excellent metal dispersion even at high metal loading $\left(\mathrm{Ni}_{15}-\mathrm{Al}_{2} \mathrm{O}_{3-\mathrm{MIL}-53}\right)$.

A first evidence of the presence of nickel in the MOF-derived materials is however given by electron diffraction (SAED), as illustrated considering a selected area of a HR-TEM image of $\mathrm{Ni}_{5}-\mathrm{Al}_{2} \mathrm{O}_{3-\mathrm{MIL}-53}$ (Fig. 2A'). Its associated SAED picture (Fig.2A") exhibits two distinct rings at distances d1 =1.8 (first ring) and $\mathrm{d} 2=1.3 \AA$ (second ring) characteristic of reticular distances present in the spinel $\mathrm{NiAl}_{2} \mathrm{O}_{4}$ structure which consists of an ensemble of tetrahedral sites occupied by bivalent $\mathrm{Ni}^{2+}$ and of octahedral sites occupied by trivalent $\mathrm{Al}^{3+}$ cations [34,35]. 

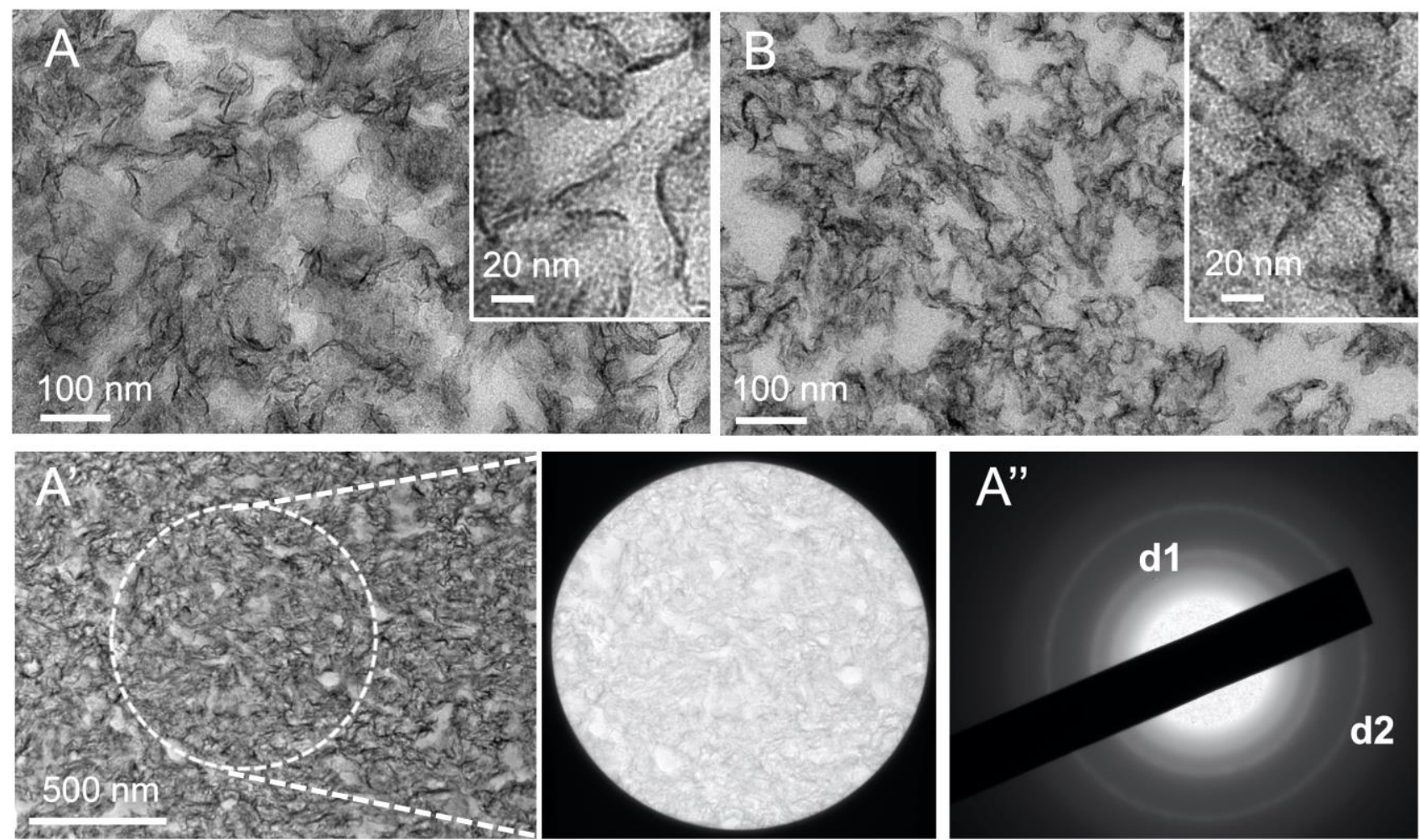

Figure 2. HR-TEM micrographs of calcined ( $\left.A, A^{\prime}\right) \mathrm{Ni}_{5}-\mathrm{Al}_{2} \mathrm{O}_{3-\mathrm{ML}-53}$ and (B) $\mathrm{Ni}_{15}-\mathrm{Al}_{2} \mathrm{O}_{3-\mathrm{MIL}-53}$ and (A') local $\mathrm{SAED}$ image for a selected low magnification zone of calcined $\mathrm{Ni}_{5}-\mathrm{Al}_{2} \mathrm{O}_{3-\mathrm{ML}-53}$; arrows indicate interwoven nanosheets layers.

The occurrence of such Ni-rich spinel phase in all the calcined $\mathrm{Ni}_{\mathrm{X}}-\mathrm{Al}_{2} \mathrm{O}_{3-\mathrm{MIL}-53}$ samples is also revealed by XRD patterns. For $\mathrm{Ni}_{5}-\mathrm{Al}_{2} \mathrm{O}_{3-\mathrm{MIL}-53}$ (Fig. 3a), three broad and tiny peaks at $2 \theta$ around $37.0^{\circ}, 45.0^{\circ}$ and $65.6^{\circ}$ are indeed visible, assignable to the (220), (400) and (440) planes of cubic spinel $\mathrm{NiAl}_{2} \mathrm{O}_{4}$ (JCPDS: 001-1299). Such phase formation reveals an intimate mixing between Ni and its aluminabased support, demonstrating that the impregnation of nickel nitrate in the parent MIL-53 with high surface area enabled an efficient dispersion of the nickel precursor along the $\left[\mathrm{Al}(\mathrm{OH}) \mathrm{O}_{4}\right]_{\mathrm{n}}$ chains decorating the pores of MIL-53(Al). The close proximity between the $\mathrm{Ni}^{2+}$ and the preformed octahedral $\mathrm{Al}^{3+}$ sites of the MIL-53(Al) inorganic chains after impregnation is indeed believed to promote the formation of the spinel $\mathrm{NiAl}_{2} \mathrm{O}_{4}$ phase after the MOF calcination step (organic removal) [24,25]. Note also that the $\mathrm{NiAl}_{2} \mathrm{O}_{4}$ zones represent only a part of the material (because of limited $\mathrm{Ni}$ loading) and must be existing as crystalline nanodomains homogeneously dispersed within an amorphous alumina matrix (no XRD signal). 


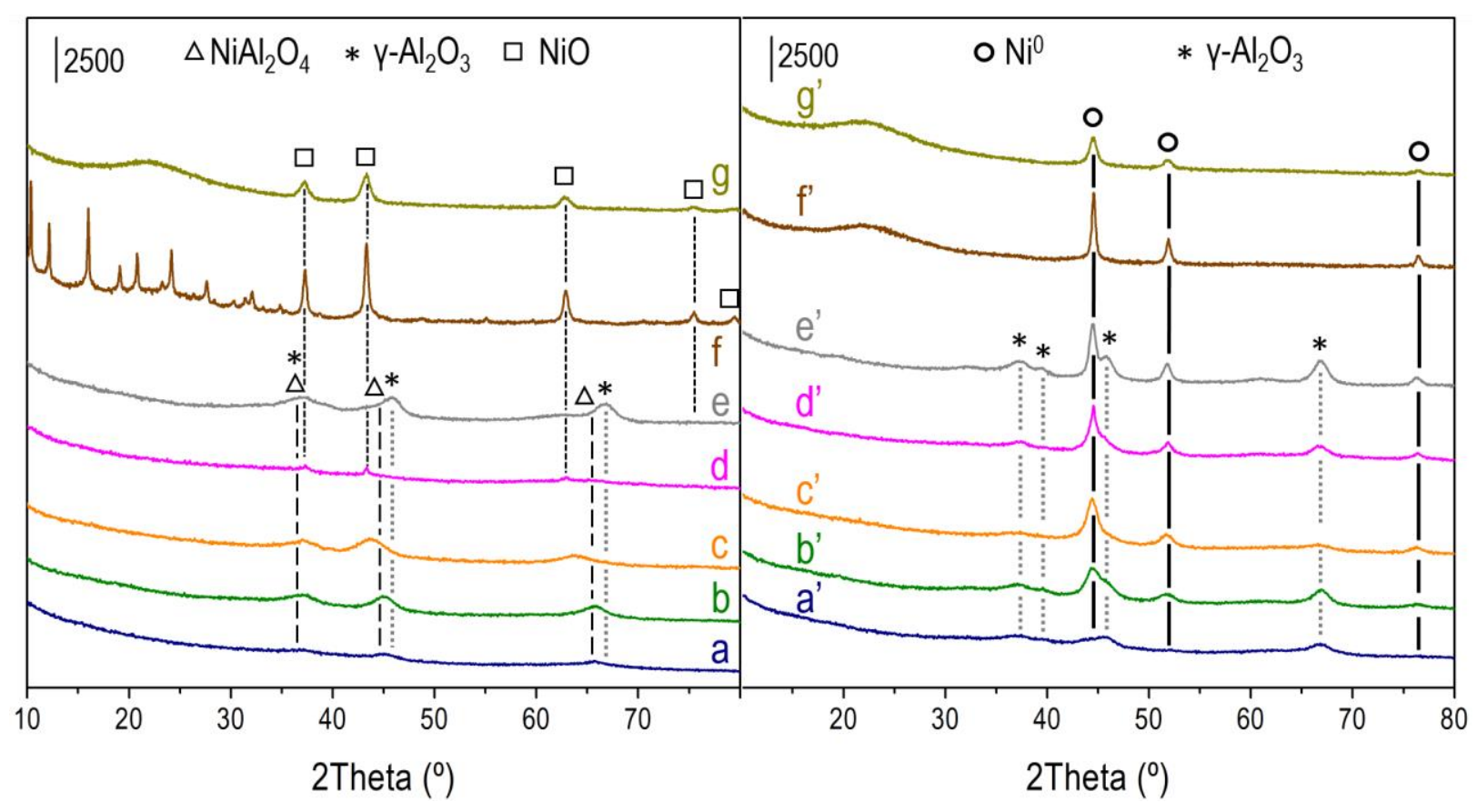

Figure 3. XRD patterns of (a-g) calcined and ( $\left.a^{\prime}-g^{\prime}\right)$ reduced samples: $\left(a-a^{\prime}\right) \mathrm{Ni}_{5}-\mathrm{Al}_{2} \mathrm{O}_{3-\mathrm{MIL}-53},\left(b-b^{\prime}\right) \mathrm{Ni}_{15}-\mathrm{Al}_{2} \mathrm{O}_{3-}$

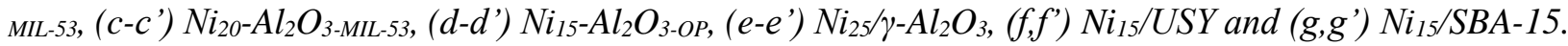

For $\mathrm{Ni}_{15}-\mathrm{Al}_{2} \mathrm{O}_{3-\mathrm{MIL} 53}$ (Fig. 3b), the diffraction peaks are still positioned at the same angles but they are more intense and thinner, revealing a higher number of bigger $\mathrm{NiAl}_{2} \mathrm{O}_{4}$ crystalline domains. Their mean size estimated by Scherrer's equation from the most intense peak $\left(2 \theta=45^{\circ}\right)$ is approximately 3 $\mathrm{nm}$ (Table 2). Upon further increase of the $\mathrm{Ni}$ content $\left(\mathrm{Ni}_{20}-\mathrm{Al}_{2} \mathrm{O}_{3}-\mathrm{MIL} 53\right.$, Fig. 3c), the three peaks start to shift to lower $2 \theta$ values, at positions equal to $37^{\circ}, 44^{\circ}$ and $62.8^{\circ}$ that approach those of the (111), (200) and (220) planes of cubic NiO (JCPDS: 01-071-4750). This suggests that Ni is still highly dispersed and bonded to alumina, but crystalline $\mathrm{NiO}$ nanoparticles and spinel $\mathrm{NiAl}_{2} \mathrm{O}_{4}$ nanodomains coexist. Such coexistence is also detected in mesoporous $\mathrm{Ni}_{15}-\mathrm{Al}_{2} \mathrm{O}_{3}-\mathrm{OP}$ (Fig. 3d). For the latter, it is worth noting that only $\mathrm{NiAl}_{2} \mathrm{O}_{4}$ was detected in the mesoporous one-pot-EISA synthetized Ni-alumina sample with $5 \mathrm{wt} \% \mathrm{Ni}$ prepared in our previous work [19,24,25], revealing some Ni extraction from the walls when more $\mathrm{Ni}$ is present. This can also be a consequence of the loss of structural ordering deduced above from $\mathrm{N}_{2}$ physisorption data. With regard to the commercial catalyst $\mathrm{Ni}_{25} / \gamma-\mathrm{Al}_{2} \mathrm{O}_{3}$, its diffractogram is typical of gamma alumina. The broadness of the peaks nevertheless suggests the possible existence of $\mathrm{NiAl}_{2} \mathrm{O}_{4}$. Also, a bump at $2 \theta$ of approximately $63^{\circ}$ also indicates the presence in the sample of a small amount of $\mathrm{NiO}$ (Fig. 3e). Turning to the reference silica-based samples, the patterns reveal the presence of crystalline Ni-based nanoparticles in the form of only $\mathrm{NiO}$ (Fig. 3f, g) and the peaks are thin and intense, indicating a much lower $\mathrm{Ni}$ dispersion than in the above aluminabased materials (Table 2). This is especially the case of $\mathrm{Ni}_{15} / \mathrm{USY}$ (Fig. 3f) which XRD pattern shows, in addition, thin peaks characteristic of the zeolite support for $2 \theta$ values below $35^{\circ}$ (IZA database). 
Table 2. Properties of the nickel-based species: mean sizes of the crystalline domains, reducibility and number of surface sites.

\begin{tabular}{|c|c|c|c|c|c|c|}
\hline \multirow{2}{*}{ Materials } & \multicolumn{2}{|c|}{$\begin{array}{l}\text { Mean size of the Ni-based } \\
\text { nanocrystals (nm) }\end{array}$} & \multicolumn{2}{|c|}{$\begin{array}{c}\text { Reducibility of calcined } \\
\text { materials }^{\mathrm{c}}\end{array}$} & \multirow{2}{*}{$\begin{array}{l}\text { Ni surface sites }{ }^{\mathrm{d}} \\
\left(\mathrm{mol} \mathbf{l}_{\text {Ni exposed }} / \mathrm{g}_{\text {catalyst })}\right.\end{array}$} & \multirow{2}{*}{$\begin{array}{c}\mathbf{T O F}^{\mathbf{e}} \\
\left(\mathbf{s}^{-1}\right)\end{array}$} \\
\hline & Calcined $^{\mathrm{a}}$ & Reduced $^{\text {b }}$ & $\begin{array}{l}\mathbf{T}_{\max } \\
\left({ }^{\circ} \mathbf{C}\right)\end{array}$ & $\begin{array}{l}\text { H}_{2} \text { uptake } \\
\left.(\mu \mathrm{mol.g})^{-1}\right)\end{array}$ & & \\
\hline $\mathrm{Ni}_{5}-\mathrm{Al}_{2} \mathrm{O}_{3-\mathrm{MIL} 53}$ & - & $-(7)$ & 750 & 918 & $2.4 .10^{-5}$ & 0.252 \\
\hline $\mathrm{Ni}_{15}-\mathrm{Al}_{2} \mathrm{O}_{3 \text {-MIL53 }}$ & $3 *$ & $6(8)$ & 720 & 2148 & $6.0 .10^{-5}$ & 0.320 \\
\hline $\mathrm{Ni}_{20}-\mathrm{Al}_{2} \mathrm{O}_{3-\mathrm{MIL} 53}$ & $4 *$ & $7(9)$ & 700 & 3263 & $7.3 .10^{-5}$ & 0.335 \\
\hline $\mathrm{Ni}_{15}-\mathrm{Al}_{2} \mathrm{O}_{3-\mathrm{OP}}$ & $9 *$ & $9(9)$ & $375 / 650$ & 1946 & $5.3 .10^{-5}$ & 0.049 \\
\hline $\mathrm{Ni}_{25} / \gamma-\mathrm{Al}_{2} \mathrm{O}_{3}$ & - & $11(12)$ & $350 / 500 / 750$ & 4174 & $5.8 .10^{-5}$ & 0.197 \\
\hline $\mathrm{Ni}_{15} / \mathrm{USY}$ & 17 & $19(22)$ & $375 / 600$ & 2042 & $1.9 .10^{-5}$ & 0.279 \\
\hline $\mathrm{Ni}_{15} / \mathrm{SBA}-15$ & $8(11)$ & $10(14)$ & $375 / 600$ & 2555 & $2.9 .10^{-5}$ & 0.103 \\
\hline
\end{tabular}

a: mean size of the $\mathrm{NiO}$ and/or $\mathrm{Ni}_{2} \mathrm{AlO}_{4}\left({ }^{*}\right)$ nanocrystals in the calcined samples as evaluated by XRD (see the experimental section for details)

b: mean size of the $\mathrm{Ni}^{0}$ nanoparticles in the reduced catalysts as estimated by XRD or TEM (in brackets)

c: temperature of peaks maxima and total $\mathrm{H}_{2}$ consumption during TPR experiments; the theoretical $\mathrm{H}_{2}$-uptake is 860 $\mu$ mol. $\mathrm{g}^{-1}$ for a sample with $5 \mathrm{wt} \% \mathrm{Ni}$.

$\mathrm{d}$ : $\mathrm{g}_{\mathrm{cat}} \times \mathrm{Ni}$ loading $\times$ dispersion $/ \mathrm{Ni}$ atomic weight

e: TOF values calculated at a temperature of $300^{\circ} \mathrm{C}$.

\subsection{Surface properties}

It is well known that $\mathrm{H}_{2} \mathrm{O}$ can have an inhibitory effect during $\mathrm{CO}_{2}$ methanation [8]. On one hand, water is a reaction product that can displace the equilibrium towards the formation of carbon dioxide, due to the reversibility of the Sabatier reaction, which inhibits $\mathrm{CO}_{2}$ conversion. On another hand, water can compete with $\mathrm{CO}_{2}$ for adsorption on the same sites [27,36,37], thus characterizing the affinity of the catalysts with water is therefore of interest. To this end, TGA experiments were carried out (Fig.S1) on the catalysts after their saturation with water to determine the hydrophobicity (h) index. This parameter, calculated as the ratio of the amount of weakly adsorbed water molecules over that of all adsorbed water molecules (desorbed at $150^{\circ} \mathrm{C}$ and $400^{\circ} \mathrm{C}$ temperature, respectively), gives an information about the strength of interaction between water and the surface (the higher the $\mathrm{h}$ index, the higher the surface hydrophobicity) [30]. The $\mathrm{h}$ index values determined for the different $\mathrm{Ni}_{\mathrm{x}}-\mathrm{Al}_{2} \mathrm{O}_{3}-$ MIL-53 samples (Table 1) are similar ( 0.6 in all cases) and tend to slightly decrease with the increase of the Ni content. In view of this value, which is significantly below 1, the interaction of the produced water with the surface of the MOF-derived Ni-alumina materials is not negligible but it is comparable among the three samples, independent of Ni loading. The strength of water adsorption is even more important on mesoporous $\mathrm{Ni}_{15}-\mathrm{Al}_{2} \mathrm{O}_{3-\mathrm{OP}}(\mathrm{h}$ index $=0.38)$, which suggests a higher proportion of surface $\mathrm{OH}$ defect sites at the surface of the walls of the mesoporous hexagonal structure, probably leading to a higher inhibitory effect of the formed water during reaction. By comparison, the commercial and silica-based samples are all more hydrophobic, and their $\mathrm{h}$ indexes vary from $0.77\left(\mathrm{Ni}_{25} / \gamma-\mathrm{Al}_{2} \mathrm{O}_{3}\right)$ to 
$0.87\left(\mathrm{Ni}_{15} / \mathrm{USY}\right)$ and $0.98\left(\mathrm{Ni}_{15} / \mathrm{SBA}-15\right)$, in line (last two samples) with what is expected for silicabased ordered materials.

Another surface property that can impact the performances of the catalysts is their capacity to adsorb $\mathrm{CO}_{2}$ since carbon dioxide adsorption is a key step in the $\mathrm{CO}_{2}$ methanation reaction $[38,39]$. This affinity was compared based on the chemical nature of the support by collecting $\mathrm{CO}_{2}$ adsorption isotherms (at $0^{\circ} \mathrm{C}$ ) on the four calcined samples with same $15 \mathrm{wt} \% \mathrm{Ni}$ content (Fig. 4). The $\mathrm{CO}_{2}$ uptakes at $\mathrm{P} / \mathrm{P}_{0}=0.3$ follow the order of: $\mathrm{Ni}_{15} / \mathrm{USY}>\mathrm{Ni}_{15} / \mathrm{SBA}-15>\mathrm{Ni}_{15}-\mathrm{Al}_{2} \mathrm{O}_{3-\mathrm{MIL}-53}>15 \mathrm{Ni}-\mathrm{Al}_{2} \mathrm{O}_{3-\mathrm{OP}}$. The higher uptakes for both silica-based materials (Fig. 4c,d) can be explained by their higher amount of micropores (especially in $\mathrm{Ni}_{15} / \mathrm{USY}$ ) and higher specific surfaces (especially in $\mathrm{Ni}_{15} / \mathrm{SBA}-15$ ) compared to the alumina-based samples (Table 1), both aspects being favourable to $\mathrm{CO}_{2}$ adsorption. For the $\mathrm{Ni}_{15} / \mathrm{USY}$ zeolite sample, an additional positive feature could be the presence of framework compensating cations, even if in low amount ( $\mathrm{Si} / \mathrm{Al}$ ratio equal to 38 ), that can strongly interact with carbon dioxide [27]. By comparison, none of the alumina materials contain micropores and their specific surface, although important, is mainly associated to an intergranular mesoporosity. However, at lower pressure, the tendency to adsorb $\mathrm{CO}_{2}$ is the highest for the MOF-derived $\mathrm{Ni}_{15}-\mathrm{Al}_{2} \mathrm{O}_{3-\mathrm{MIL}-53}$ sample (Fig. 4a, right) and next for $\mathrm{Ni}_{15}-\mathrm{Al}_{2} \mathrm{O}_{3-\mathrm{OP}}$ material. This faster $\mathrm{CO}_{2}$ adsorption, indicative of the existence of some stronger adsorption sites on the alumina supports, might play a role during catalysis that involves a dynamic adsorption/activation process.
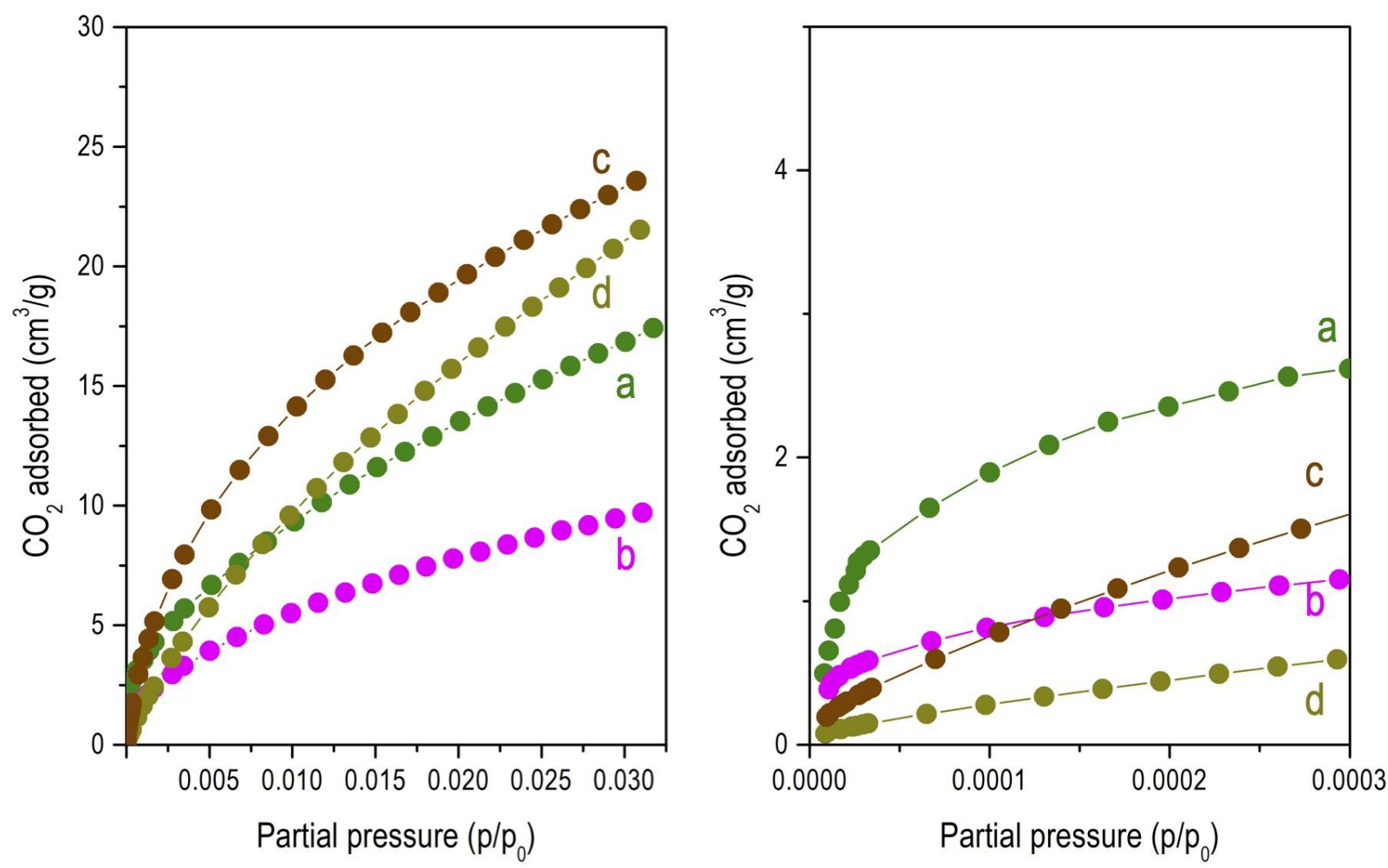
Figure 4. $\mathrm{CO}_{2}$ adsorption isotherms collected on calcined (a) $\mathrm{Ni}_{15}-\mathrm{Al}_{2} \mathrm{O}_{3-\mathrm{ML}-53}$, (b) $\mathrm{Ni}_{15}-\mathrm{Al}_{2} \mathrm{O}_{3-O P}$, (c) $\mathrm{Ni}_{15} / \mathrm{USY}$, (d) $N i_{15} / S B A-15 ; P / P_{0}$ between 0 to 0.03 (left) and zoom between 0 and 0.0003 (right)

\subsection{Reducibility of the nickel-based species}

The reducibility of the calcined materials was investigated by $\mathrm{H}_{2}$-TPR measurements. During this treatment, the oxidized nickel species present in the materials are expected to be transformed to metallic $\mathrm{Ni}^{0}$, the nickel state responsible for $\mathrm{H}_{2}$ dissociation in the $\mathrm{CO}_{2}$ methanation reaction. For all $\mathrm{Ni}_{\mathrm{x}}-\mathrm{Al}_{2} \mathrm{O}_{3-\mathrm{MIL}-53}$ samples, the reduction profiles are very similar (Fig. 5Aa-c), with only one peak at high temperature $\left(650-800^{\circ} \mathrm{C}\right)$, typical of $\mathrm{Ni}$ ions strongly interacting with the alumina phase such as $\mathrm{Ni}^{2+}$ in $\mathrm{NiAl}_{2} \mathrm{O}_{4}[24,40]$. Notably, no peak is detected at temperatures below $500^{\circ} \mathrm{C}$, which attests of the absence of $\mathrm{NiO}$ nanoparticles weakly attached on the alumina support [40]. A progressive small displacement of the peak towards lower temperatures is nevertheless observed when increasing the $\mathrm{Ni}$ loading, revealing a tendency of the Ni-based species to be more and more reducible as the sample becomes Ni-richer. All these features are in good agreement with the above HR-TEM and XRD data that revealed a high nickel dispersion in the form of mainly $\mathrm{NiAl}_{2} \mathrm{O}_{4}$ in $\mathrm{Ni}_{5}-\mathrm{Al}_{2} \mathrm{O}_{3-\mathrm{MIL}-53}$ but a coexistence of $\mathrm{NiAl}_{2} \mathrm{O}_{4}$ and (more reducible) $\mathrm{NiO}$-like species as the $\mathrm{Ni}$ loading is raised $\left(\mathrm{Ni}_{20}-\mathrm{Al}_{2} \mathrm{O}_{3}\right.$ MIL-53) (Fig. 3c). The still high reduction temperature for the latter sample ( $\mathrm{T}=690^{\circ} \mathrm{C}$ ) shows that the $\mathrm{NiO}$ species strongly interacts with the surface of the alumina walls and does not consist of free $\mathrm{NiO}$ particles weakly attached to the support. The occurrence of only one peak for this sample, moreover, suggests that the $\mathrm{NiO}$ and $\mathrm{NiAl}_{2} \mathrm{O}_{4}$ nanoparticles are not distinct but rather consist of a defective $\mathrm{Ni}$ aluminate phase whose flexible structure is related to both $\mathrm{NiO}$ and $\mathrm{NiAl}_{2} \mathrm{O}_{4}$. 

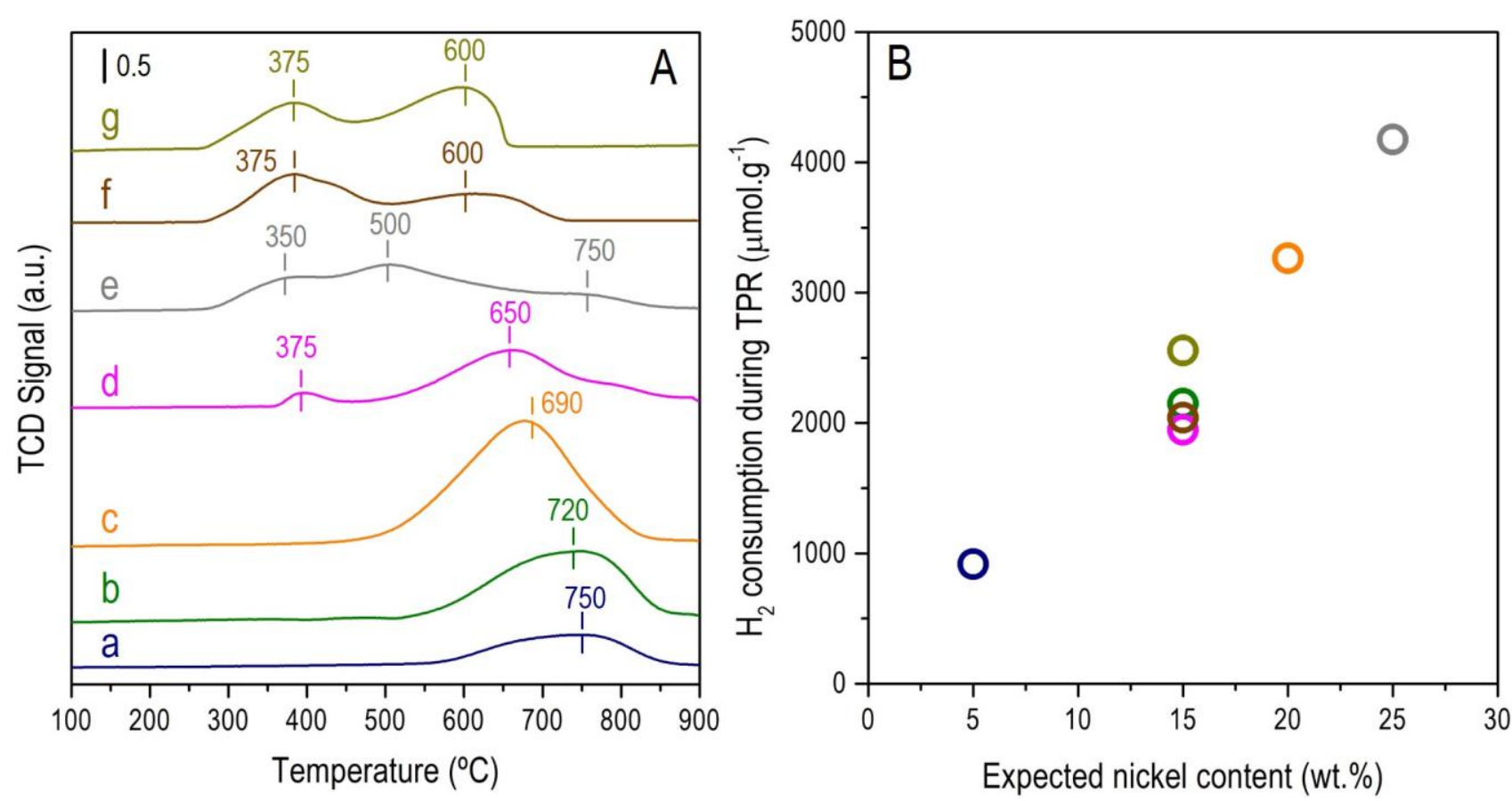

Figure 5. (A) $\mathrm{H}_{2}$-TPR profiles of calcined samples: (a) $\mathrm{Ni}_{5}-\mathrm{Al}_{2} \mathrm{O}_{3-M I L-53}$, (b) $\mathrm{Ni}_{15}-\mathrm{Al}_{2} \mathrm{O}_{3-\mathrm{MIL}-53}$, (c) $\mathrm{Ni}_{20}-\mathrm{Al}_{2} \mathrm{O}_{3-M I L}$ 53, (d) $\mathrm{Ni}_{15}-\mathrm{Al}_{2} \mathrm{O}_{3-\mathrm{OP}},(e) \mathrm{Ni}_{25} / \gamma-\mathrm{Al}_{2} \mathrm{O}_{3}$, (f) $\mathrm{Ni}_{15} / \mathrm{USY}$ and $(\mathrm{g}) \mathrm{Ni} \mathrm{i}_{15} / \mathrm{SBA}-15$. (B) Experimental $\mathrm{H}_{2}$ uptakes as a function of the impregnated $\mathrm{Ni}$ content: $\mathrm{Ni}_{5}-\mathrm{Al}_{2} \mathrm{O}_{3-\mathrm{MLL}-53}$ (dark blue), $\mathrm{Ni}_{15}-\mathrm{Al}_{2} \mathrm{O}_{3-\mathrm{MLL}-53}$ (dark green), $\mathrm{Ni}_{20}-\mathrm{Al}_{2} \mathrm{O}_{3-}$ MIL-53 (orange), $\mathrm{Ni}_{15}-\mathrm{Al}_{2} \mathrm{O}_{3-\mathrm{OP}}$ (rose), $\mathrm{Ni} i_{15} / \mathrm{USY}$ (brown), $\mathrm{Ni} i_{15} / \mathrm{SBA}-15$ (army green) and $\mathrm{Ni}_{25} / \gamma-\mathrm{Al}_{2} \mathrm{O}_{3}$ (grey).

For $\mathrm{Ni}_{15}-\mathrm{Al}_{2} \mathrm{O}_{3-\mathrm{OP}}\left(\right.$ Fig. 5d), a main peak at high temperature $\left(\sim 700{ }^{\circ} \mathrm{C}\right)$ is still observed, but it is accompanied by a less intense one centred at $\sim 400^{\circ} \mathrm{C}$ typical of the reduction of $\mathrm{NiO}$ species weakly interacting with the $\mathrm{Al}_{2} \mathrm{O}_{3}$ matrix, which fully agrees with the above XRD detection of crystalline $\mathrm{NiO}$ in this sample. For commercial $\mathrm{Ni}_{25} / \gamma-\mathrm{Al}_{2} \mathrm{O}_{3}$ (Fig. 5e), reduction at lower temperature prevails, suggesting that the $\mathrm{NiO}$ species are weakly bounded, probably due to the combination of a slightly higher Ni content and intermediate pore volume (Table 1) that drive Ni to sinter in this sample. For both $\mathrm{Si}$-based $\mathrm{Ni}_{15} / \mathrm{USY}$ and $\mathrm{Ni}_{15} / \mathrm{SBA}-15$ (Fig. 5f, g), two peaks are also systematically seen, at low $\left(\mathrm{T}<500{ }^{\circ} \mathrm{C}\right)$ and high $\left(\mathrm{T}>500{ }^{\circ} \mathrm{C}\right)$ temperature range, assignable to $\mathrm{NiO}$ nanoparticles located on the surface of the silica (zeolite of SBA-15) grains and trapped in the pores, respectively. In the case of $\mathrm{Ni}_{15} / \mathrm{USY}$, the high temperature peak may also involve the reduction of $\mathrm{Ni}^{2+}$ cations positioned at framework compensating sites in the zeolite sample [41,42].

It is also important to note that, for all materials, the amount of $\mathrm{H}_{2}$ consumed between 200 and $900{ }^{\circ} \mathrm{C}$ during the TPR experiment (values reported in Table 2) is in very good agreement with the theoretical $\mathrm{H}_{2}$-uptake expected when considering the $\mathrm{Ni}$ loading and assuming a bivalent $\mathrm{Ni}$ oxidation state in the calcined samples. This agreement is better shown by the linear correlation obtained when reporting these $\mathrm{H}_{2}$-upatkes as a function of the amount of impregnated nickel (Fig. 5B). 


\subsection{Dispersion and distribution of the $\mathrm{Ni}^{0}$ nanoparticles}

The evolution of the state of the Ni-based species after reduction was analysed from the X-Ray diffractograms of the reduced materials reported in Figure 3 together with those before reduction (already discussed above). For all MOF-based materials (Fig. 3a'-c'), the reduction treatment contributed to the formation of new diffraction peaks at $2 \theta$ of $44.5^{\circ}, 51.9^{\circ}$ and $76^{\circ}$ attributed to the (111), (200) and (220) planes of crystalline $\mathrm{Ni}^{0}$, respectively (JCPDS: 03-065-0380). In addition, bands typical of $\gamma-\mathrm{Al}_{2} \mathrm{O}_{3}$ systematically appear, asserting on the segregation of the crystalline $\mathrm{NiAl}_{2} \mathrm{O}_{4}$ nanospecies into metallic $\mathrm{Ni}^{0}$ and alumina. The isolated peak at $51.9^{\circ}$ was used to evaluate the mean $\mathrm{Ni}^{0}$ nanoparticle sizes (by Scherrer's equation), leading to values between 6 and $7 \mathrm{~nm}$ (Table 2).

These mean sizes values are also in good agreement, even if slightly smaller, with those estimated from the histograms of particle sizes established by measuring the size of approximately 500 nanoparticles in HR-TEM images, (Fig. 6, Table 2). Despite the good resolution of the HR-TEM images, this discrepancy could be due to contrast issues making the detection of the smallest nanoparticles $(2-4 \mathrm{~nm})$ on the alumina grains uneasy by this technique. The histograms of $\mathrm{Ni}^{0}$ particles sizes visualize well the $\mathrm{Ni}^{0}$ particles sizes distribution and its tendency to shift towards higher sizes when more nickel is present in the $\mathrm{Ni}^{0}{ }_{\mathrm{x}}-\mathrm{Al}_{2} \mathrm{O}_{3-\mathrm{MIL} 53}$ catalysts (Fig. 6a'-c'). Nevertheless, the mean size of $9.4 \mathrm{~nm}$ in $\mathrm{Ni}^{0}{ }_{20}-\mathrm{Al}_{2} \mathrm{O}_{3-\mathrm{MIL} 53}$ with the highest $\mathrm{Ni}$ loading remains significantly below the value of 12 nm evaluated for the commercial $\mathrm{Ni}_{25} / \gamma-\mathrm{Al}_{2} \mathrm{O}_{3}$ catalyst (Fig. 6d'). 

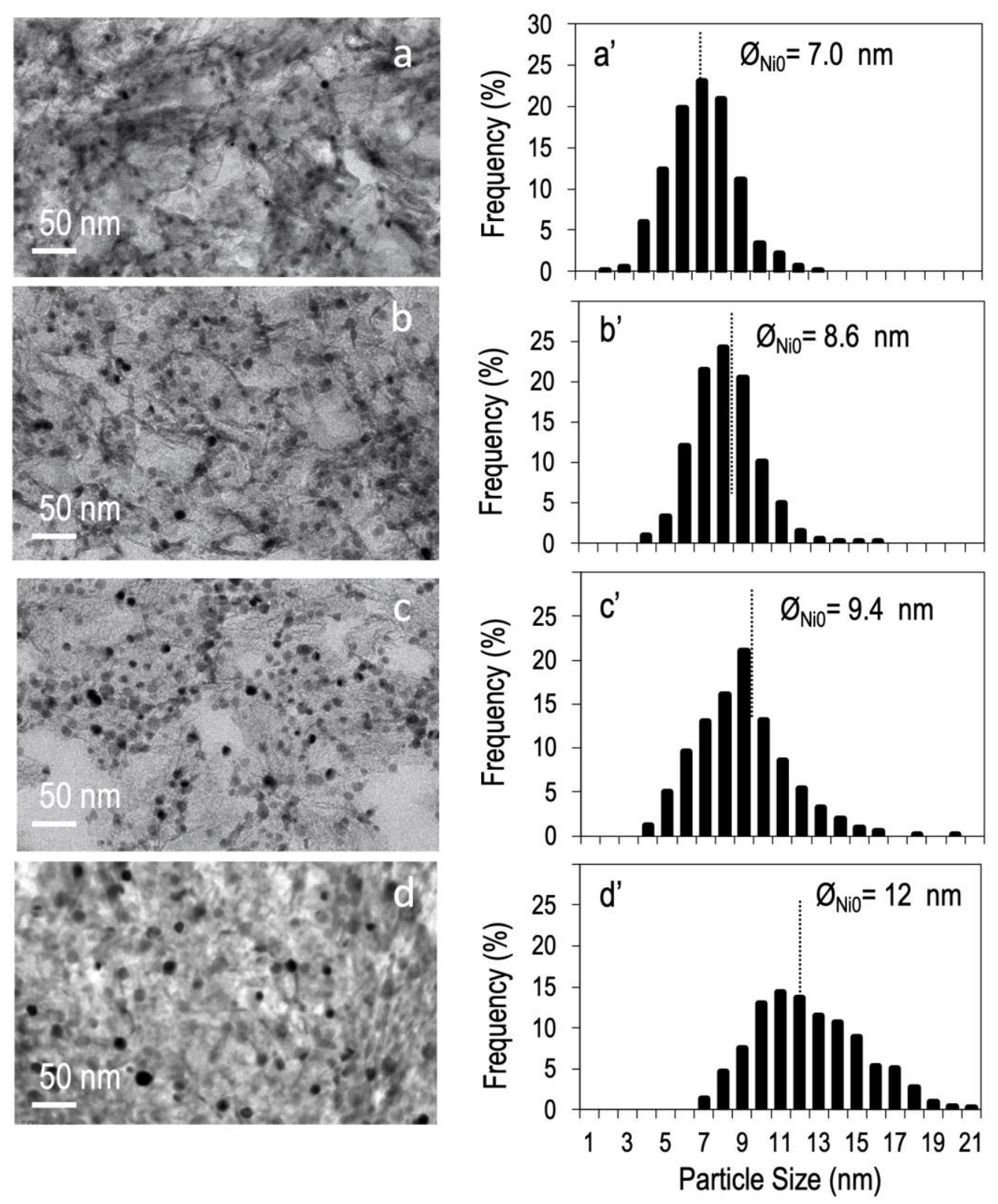

Figure 6. (a-d) HR-TEM micrographs and ( $\left.a^{\prime}-d^{\prime}\right)$ distribution of particles sizes in reduced (a, $\left.a^{\prime}\right) \mathrm{Ni}_{5}-\mathrm{Al}_{2} \mathrm{O}_{3}$ MIL-53, ( $\left.b, b^{\prime}\right) \mathrm{Ni}_{15}-\mathrm{Al}_{2} \mathrm{O}_{3-\mathrm{ML}-53},\left(c, c^{\prime}\right) \mathrm{Ni}_{20}-\mathrm{Al}_{2} \mathrm{O}_{3-\mathrm{MLL}-53}$ and (d,d') $\mathrm{Ni}_{25} / \gamma-\mathrm{Al}_{2} \mathrm{O}_{3}$.

These values are moreover smaller than the sizes of $\mathrm{Ni}^{0}$ in both silica-based catalysts in which mean sizes of $14 \mathrm{~nm}\left(\mathrm{Ni}_{15} / \mathrm{SBA}-15\right)$ and even $22 \mathrm{~nm}\left(\mathrm{Ni}_{15} / \mathrm{USY}\right)$ are reached as seen in the micrographs (Fig. $\mathbf{S 2}$ in supplementary information) and X-Ray diffractograms of the samples (thinner peaks of $\mathrm{Ni}^{0}$ in Fig. 3f',g'). Such lower nickel dispersion on the silica supports, especially on the zeolitic one, agrees with the weaker metal-support interaction depicted from $\mathrm{H}_{2}$-TPR and already tackled in literature when comparing oxides others than alumina, like $\mathrm{ZrO}_{2}, \mathrm{TiO}_{2}$ or $\mathrm{SiO}_{2}$, as nickel supports [43]. It is also worth noting that the sizes in the $\mathrm{Ni}^{0}{ }_{\mathrm{x}}-\mathrm{Al}_{2} \mathrm{O}_{3-\mathrm{MIL}} 3$ series of catalysts are below than those previously reported in the literature for metallic nanoparticles supported on other MOF-based materials (between 9 and 20 $\mathrm{nm})[23,44]$. All these features show that the strategy of occluding nickel inside the pores of MIL-53 
before calcining it to form the alumina support is an efficient route to produce small nickel particles, even at high nickel loadings highlighting the benefit of using MIL-53(Al) both as nickel support and alumina precursor for the preparation of a nickel alumina catalyst with improved nickel dispersion.

Moreover, in the three $\mathrm{Ni}^{0}{ }_{\mathrm{x}}-\mathrm{Al}_{2} \mathrm{O}_{3-\mathrm{MIL} 53}$ catalysts, and independently of the nickel loading, the metal nanoparticles always appear homogeneously dispersed over the alumina support that still takes the form of interwoven nanosheets (Fig. 3a-c). Such preservation of the textural properties after reduction is also deduced from the $\mathrm{N}_{2}$ sorption isotherms of the $\mathrm{Ni}^{0}{ }_{\mathrm{x}}-\mathrm{Al}_{2} \mathrm{O}_{3-\mathrm{MIL} 53}$ catalysts that still exhibit a type IV-related physisorption profile with a slit-like hysteresis typical of a layered material with unorganized interlayered pores (Fig. 1a'-c'). The specific surfaces deduced from the curves are however slightly decreased compared to those in the calcined materials (Table 1), indicating that some - although limited - structural shrinkage occurred at the high reduction temperature of $800{ }^{\circ} \mathrm{C}$. This is accompanied by a small increase of the diameters of pores, possibly attributable to the phase transformation of $\mathrm{NiAl}_{2} \mathrm{O}_{4}$ into $\gamma-\mathrm{Al}_{2} \mathrm{O}_{3}$ and to $\mathrm{Ni}^{0}$ nanoparticles formation spacing apart the nanosheets one from another.

\subsection{Catalytic performances}

Figure 7 shows the results of catalytic measurements carried out in the same conditions (detailed in section 2.3) on all the catalysts. They are reported in terms of $\mathrm{CO}_{2}$ conversion (Fig. 7a-g) and $\mathrm{CH}_{4}$ selectivity (Fig. 7a'-g') as a function of the reaction temperature (light-off curves). For all catalysts, the $\mathrm{CO}_{2}$ conversion progressively increases with the temperature between c.a. 250 to $350^{\circ} \mathrm{C}$, afterwards it starts decreasing because of attaining the thermodynamic equilibrium (dotted lines in Fig. 7) that is unfavourable to the reaction upon heating. 


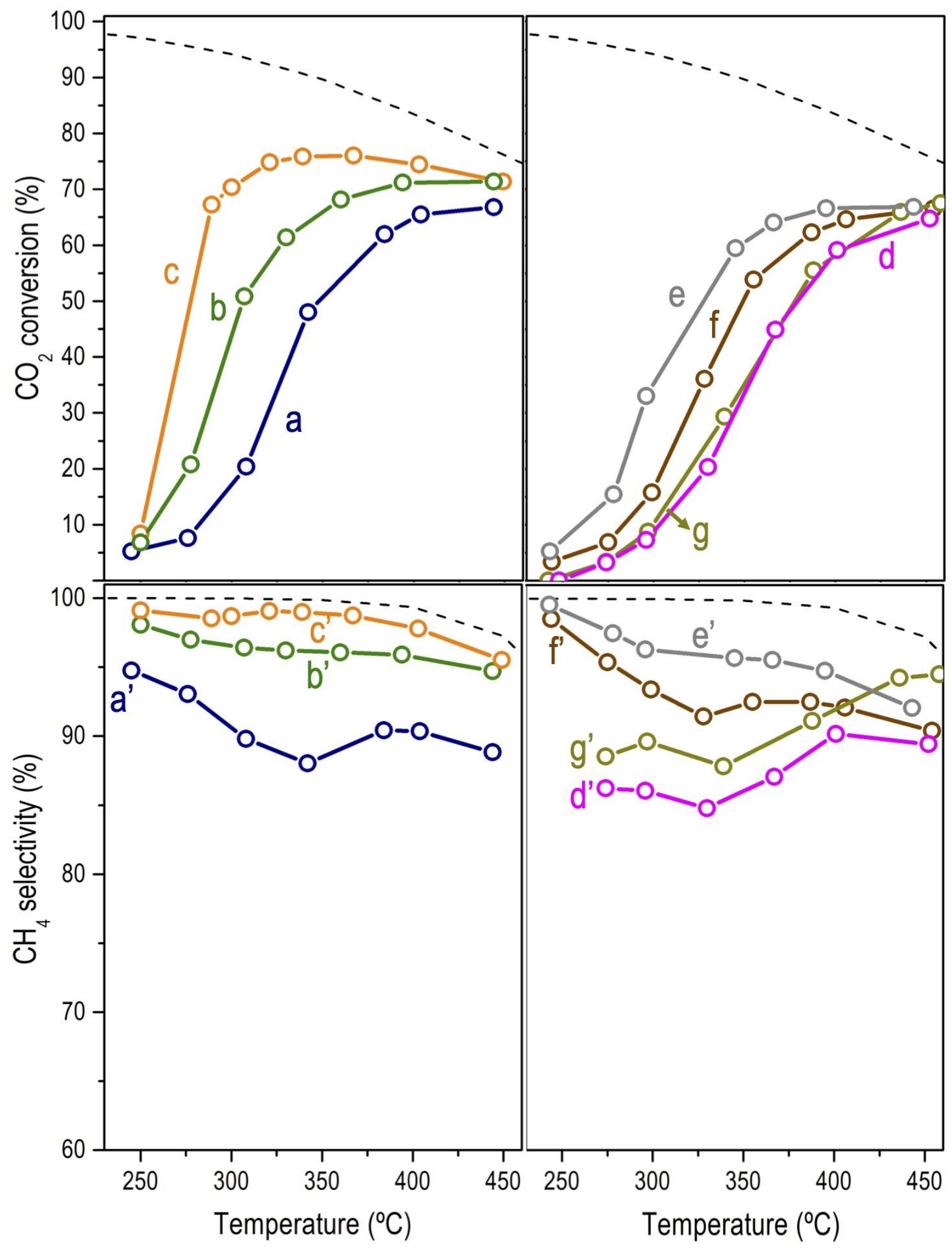

Figure 7. (a-g) $\mathrm{CO}_{2}$ conversions and ( $\left.a^{\prime}-g^{\prime}\right) \mathrm{CH}_{4}$ selectivity obtained at increasing temperatures during catalytic tests on reduced: (a, $\left.a^{\prime}\right) \mathrm{Ni}_{5}-\mathrm{Al}_{2} \mathrm{O}_{3-\mathrm{MIL}-53},\left(b, b^{\prime}\right) \mathrm{Ni}_{15}-\mathrm{Al}_{2} \mathrm{O}_{3-M I L-53},\left(c, c^{\prime}\right) \mathrm{Ni}_{20}-\mathrm{Al}_{2} \mathrm{O}_{3-\mathrm{MIL}-53}$, (d, d') $\mathrm{Ni}_{15-}$ $\mathrm{Al}_{2} \mathrm{O}_{3-\mathrm{OP}},\left(e, e^{\prime}\right) \mathrm{Ni}_{25}-\mathrm{y}-\mathrm{Al}_{2} \mathrm{O}_{3},\left(f, f^{\prime}\right) \mathrm{Ni} i_{15} / \mathrm{USY}$ and $\left(g, g^{\prime}\right) \mathrm{Ni} i_{15} / \mathrm{SBA}-15$. The dotted black line corresponds to values at thermodynamic equilibrium. 
Before discussing in detail the catalytic performances revealed by the samples from the present work, some insights on $\mathrm{CO}_{2}$ methanation (Sabatier) reaction mechanism over Ni/alumina catalysts must be mentioned. For instance, Cárdenas-Arenas et al. [45] verified by carrying out an isotopic and in situ DRIFTS study that the reaction starts through $\mathrm{CO}_{2}$ chemisorption over hydroxyl groups created by $\mathrm{H}_{2}$ reduction in the $\mathrm{NiO}-\mathrm{Al}_{2} \mathrm{O}_{3}$ interface. Afterwards, the formation of $\mathrm{H}_{2} \mathrm{O}$ and $\mathrm{CO}$ or $\mathrm{CH}_{4}$ (both arising from formate species acting as intermediates) was verified. Authors concluded that $\mathrm{CO}_{2}$ chemisorption/dissociation and $\mathrm{H}_{2} \mathrm{O}$ formation occur on the same active sites. Consequently, the slower release of water as well as the accumulation of formate species in these sites limit the chemisorption and dissociation of further $\mathrm{CO}_{2}$ molecules. Furthermore, Lim et al. [46] carried out a kinetic study using a batch reactor and considered a mechanism again initiated by $\mathrm{CO}_{2}$ chemisorption and dissociation on the surface of the catalyst, leading to $\mathrm{CO}$ and $\mathrm{O}$ species. In this case, authors considered the dissociation of the adsorbed $\mathrm{CO}$ as the rate-limiting step. Finally, Vogt et al. [47] performed a theoretical study over $\mathrm{Ni}$ catalysts with $\mathrm{Ni}^{0}$ particle sizes varying from 1 to $6 \mathrm{~nm}$ and again proposed the dissociation and further hydrogenation of $\mathrm{CO}$ as rate-limiting step.

When analysing the evolution of the $\mathrm{CO}_{2}$ conversion in the $\mathrm{Ni}_{\mathrm{x}}-\mathrm{Al}_{2} \mathrm{O}_{3-\mathrm{MIL}-53}$ series of catalysts (Fig. 7a-c), it is noticeable that $\mathrm{CO}_{2}$ conversion increases linearly with respect to the nickel content. This trend is clearly visualized when plotting the $\mathrm{CO}_{2}$ conversions obtained at $300^{\circ} \mathrm{C}$ as a function of the Ni weight percentages (pink hexagons, Fig. 8). To explain this linear relationship, it can be recalled

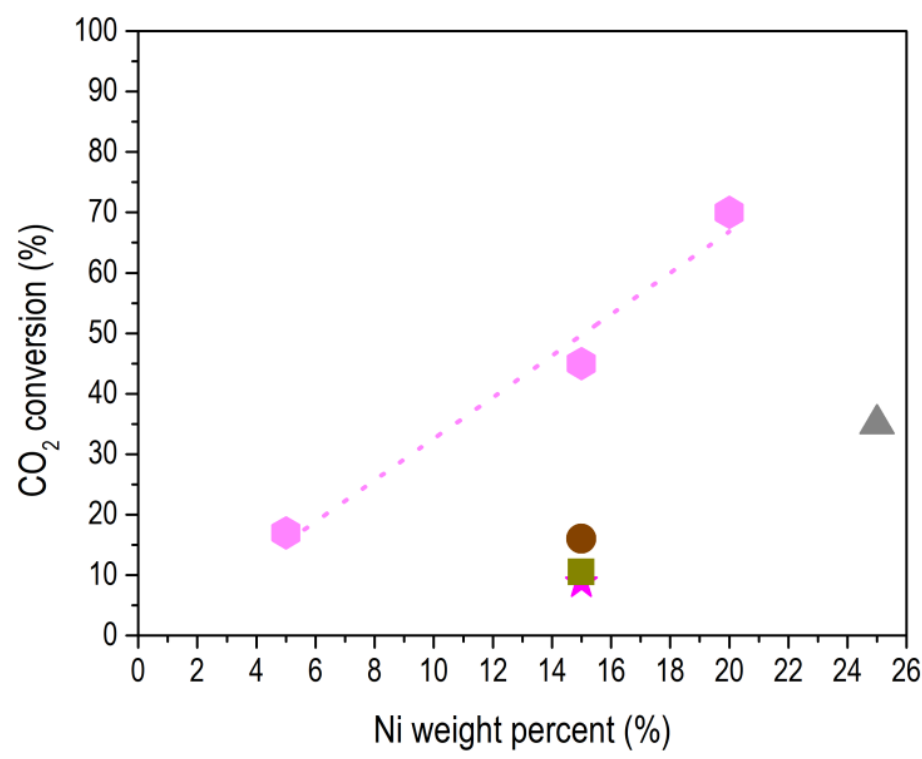

Figure 8. $\mathrm{CO}_{2}$ conversions at $300^{\circ} \mathrm{C}$ (at steady state conditions) as a function of the $\mathrm{Ni}$ weight percent in the prepared catalysts: $\mathrm{Ni}_{\mathrm{x}}-\mathrm{Al}_{2} \mathrm{O}_{3-\mathrm{MIL}-53}$ (hexagons), $\mathrm{Ni}_{15}-\mathrm{Al}_{2} \mathrm{O}_{3-\mathrm{OP}}$ (star), $\mathrm{Ni}_{2} / \mathrm{\gamma}-\mathrm{Al}_{2} \mathrm{O}_{3}$, (triangle), $\mathrm{Ni}_{15} / \mathrm{USY}$ (circle), $\mathrm{Ni}_{15} / \mathrm{SBA}-15$ (square)

that (i) the nickel dispersion is comparable in all three catalysts, hence the number of $\mathrm{Ni}^{0}$ surface atoms should be proportional to the $\mathrm{Ni}$ content, (ii) they exhibit close specific surfaces (alumina) for $\mathrm{CO}_{2}$ 
adsorption and (iii) they are characterized by comparable $\mathrm{h}$ indexes which suggests a similar sensitivity to the inhibitory effect of water formed during reaction (Table 1). Consequently, it is expected that an increase in the number of available nickel sites for $\mathrm{H}_{2}$ dissociation boosts the supply of $\mathrm{H}$ atoms, required for the hydrogenation of the $\mathrm{CO}_{2}$ chemisorbed over the catalyst's surface.

The $\mathrm{CO}_{2}$ conversion curves for the other catalysts (Fig. 7d-g) and their levels of conversions at $300^{\circ} \mathrm{C}$ (Fig. 8) clearly show that they are significantly less active than the MOF-derived $\mathrm{Ni}_{\mathrm{x}}-\mathrm{Al}_{2} \mathrm{O}_{3-\mathrm{MIL}-53}$ catalysts. Amongst them, commercial $\mathrm{Ni}_{25} / \mathrm{y}-\mathrm{Al}_{2} \mathrm{O}_{3}$ with the highest $\mathrm{Ni}$ content, reaches a level of $\mathrm{CO}_{2}$ conversion at $300^{\circ} \mathrm{C}$ (triangle in Fig. 8) slightly below the one attained on Ni-poorer $\mathrm{Ni}_{15}-\mathrm{Al}_{2} \mathrm{O}_{3-\mathrm{MIL}}$ 53. This lower catalytic activity might be explained by the lower Ni dispersion (by more than 25\%) in $\mathrm{Ni}_{25} / \mathrm{y}-\mathrm{Al}_{2} \mathrm{O}_{3}$ (Table 2 and Fig. 6). The same reason could also contribute to the poor activities observed for both $\mathrm{Ni}_{15} / \mathrm{USY}$ (Fig. 7f) and $\mathrm{Ni}_{15} / \mathrm{SBA}-15$ (Fig. 7g) but an additional effect might exist, on these two silica-based catalysts. Indeed, even if their hydrophobic character (high $\mathrm{h}$ index, Table 2) should be favourable (less inhibitory role of water) and if their capacity of adsorption of $\mathrm{CO}_{2}$ at a $\mathrm{P} / \mathrm{P}_{0}$ pressure of 0.03 is higher than in the alumina sample (due to their higher pores volumes), the $\mathrm{CO}_{2}$ adsorption is less favourable at very low pressure (Fig. 4), suggesting a more difficult $\mathrm{CO}_{2}$ activation process on the silica supports. This would be in line with literature reporting that the SBA-15 support is not able to significantly adsorb and activate $\mathrm{CO}_{2}$, and that both $\mathrm{CO}_{2}$ adsorption/activation and $\mathrm{H}_{2}$ dissociation are assumed to occur over the same $\mathrm{Ni}^{0}$ active sites [48]. For the zeolitic catalysts, the $\mathrm{CO}_{2}$ adsorption as carbonates could occur over the compensating cations [27,32] and on extraframework aluminium species (EFAL) [39], which may explain the slightly better performances of this catalyst compared to $\mathrm{Ni}_{15} / \mathrm{SBA}-15$ (Fig. 7f and 7g). Turning now to the $\mathrm{Ni}_{15}-\mathrm{Al}_{2} \mathrm{O}_{3-\mathrm{OP}}$ catalyst, its very poor activity (Fig. 7d and star in Fig. 8) cannot be attributed to its metal dispersion (as good as in $\mathrm{Ni}_{\mathrm{x}}-\mathrm{Al}_{2} \mathrm{O}_{3-\mathrm{MIL}-53}$ ) but rather to its poor textural properties (specific surface 4 times lower than in $\mathrm{Ni}_{\mathrm{x}}-$ $\mathrm{Al}_{2} \mathrm{O}_{3-\mathrm{MIL}-53}$ ) associated to a poor $\mathrm{CO}_{2}$ adsorption capacity (Fig. 4d). The $\mathrm{h}$ index for this sample is also about two times lower (Table 2), revealing an enhanced inhibitory role of water. These results are quite consensus with the TOF values illustrated in Table 2. For MOF-derived $\mathrm{Ni}_{\mathrm{x}}-\mathrm{Al}_{2} \mathrm{O}_{3-\mathrm{MIL}-53}$ catalysts, the increment of $\mathrm{Ni}$ loading did not affect TOF values and the TOF of $\mathrm{Ni}_{20}-\mathrm{Al}_{2} \mathrm{O}_{3-\mathrm{MIL}-53}$ $\left(0.335 \mathrm{~s}^{-1}\right)$ containing $20 \mathrm{wt} \% \mathrm{Ni}$ remains as good as the TOF of $\mathrm{Ni}_{5}-\mathrm{Al}_{2} \mathrm{O}_{3-\mathrm{MIL}-53}\left(0.252 \mathrm{~s}^{-1}\right)$ containing $5 \mathrm{wt} \% \mathrm{Ni}$. Not to mention that the latter samples possess higher TOF values than other catalysts having poorer metal dispersion and textural properties (Table 2).

To evaluate the performances of the catalysts, not only their activity but also their selectivity to the desired reaction (here $\mathrm{CH}_{4}$ ) is important. Here, again, the MOF-derived $\mathrm{Ni}_{\mathrm{x}}-\mathrm{Al}_{2} \mathrm{O}_{3-\mathrm{MIL}-53}$ catalysts are clearly the most performing, especially $\mathrm{Ni}_{15}-\mathrm{Al}_{2} \mathrm{O}_{3-\mathrm{MIL}-53}$ and $\mathrm{Ni}_{20}-\mathrm{Al}_{2} \mathrm{O}_{3-\mathrm{MIL}-53}$ that give always high 
selectivity to $\mathrm{CH}_{4}$, between 96 and 99\%, whatever the temperature is (Fig. 7b'-c'). The selectivity is lower on the other catalysts, especially in the $300-350^{\circ} \mathrm{C}$ temperature range. Based on Operando FTIR studies reported in the literature for Ni-supported zeolites (aluminosilicates) [39], the reduction in $\mathrm{CH}_{4}$ selectivity at $300-350{ }^{\circ} \mathrm{C}$ could be explained by an accumulation of adsorbed $\mathrm{CO} /$ formate species (arising from $\mathrm{CO}_{2}$ dissociation) over the catalysts surface, limiting its dissociation/hydrogenation.

For the sake of completion, the catalytic stability of the most performing $\mathrm{Ni}_{20}-\mathrm{Al}_{2} \mathrm{O}_{3-\mathrm{MIL}-53}$ catalyst was assessed by running the reaction for 10 or $20 \mathrm{~h}$ at $350^{\circ} \mathrm{C}$ and comparing it to the stability of commercial $\mathrm{Ni}_{25} / \gamma-\mathrm{Al}_{2} \mathrm{O}_{3}$ material tested in the same conditions (Fig. 9). This temperature was chosen, although given $\mathrm{CO}_{2}$ conversion levels approaching those of thermodynamic equilibrium, to enhance eventual $\mathrm{Ni}$ deactivation processes by sintering, if existing. In agreement with the previous section, the performances were higher for both $\mathrm{Ni}_{15}-\mathrm{Al}_{2} \mathrm{O}_{3}$ MIL-53 and $\mathrm{Ni}_{20}-\mathrm{Al}_{2} \mathrm{O}_{3}$ MIL-53 $\left(70-75 \% \mathrm{CO}_{2}\right.$ conversion and $99 \% \mathrm{CH}_{4}$ selectivity) than for $\mathrm{Ni}_{25} / \gamma-\mathrm{Al}_{2} \mathrm{O}_{3}\left(60 \% \mathrm{CO}_{2}\right.$ conversion and $95 \% \mathrm{CH}_{4}$ selectivity). More importantly, none of the catalysts suffered a noticeable deactivation during the test duration, neither in term of activity nor of selectivity. Moreover, the TEM micrograph collected for the spent $\mathrm{Ni}_{15}-\mathrm{Al}_{2} \mathrm{O}_{3}$ MIL-53 catalyst after undergoing the reaction for $20 \mathrm{~h}$ shows the conservation of both its textural properties and high nickel dispersion. The average $\mathrm{Ni}^{0}$ particle size of $7.3 \mathrm{~nm}$ estimated from the histograms indicates an absence of metal sintering. This further proves that the $\mathrm{Ni}-\mathrm{Al}_{2} \mathrm{O}_{3}$ catalysts derived from MIL-53 constitute interesting materials for $\mathrm{CO}_{2}$ methanation reaction for the synthesis of $\mathrm{CH}_{4}$ natural gas.
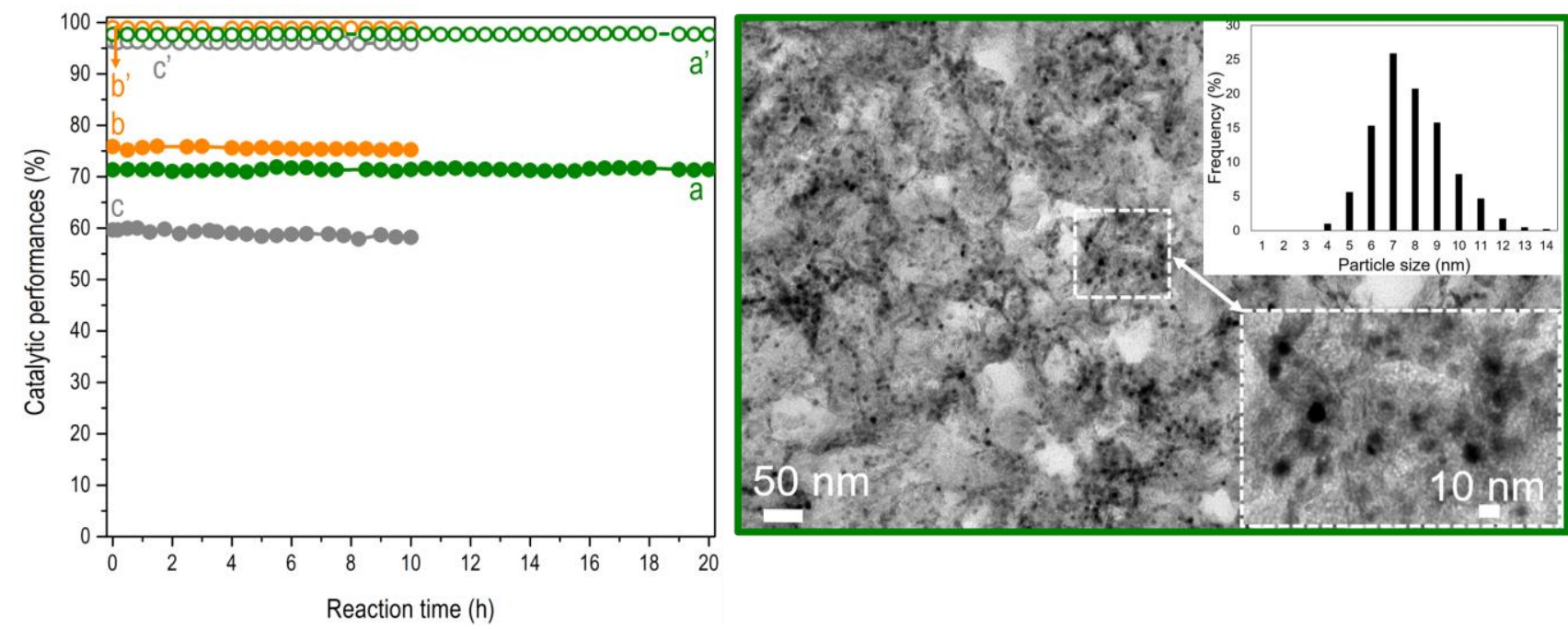

Figure 9. A. Stability test results in terms of (a-c) $\mathrm{CO}_{2}$ conversion and ( $\left.a^{\prime}-c^{\prime}\right) \mathrm{CH}_{4}$ selectivity of $\left(a, a^{\prime}\right) \mathrm{Ni}_{15-}$ $\mathrm{Al}_{2} \mathrm{O}_{3-\mathrm{MIL}-53},\left(\mathrm{~b}, \mathrm{~b}^{\prime}\right) \mathrm{Ni}_{20}-\mathrm{Al}_{2} \mathrm{O}_{3-\mathrm{ML}-53}$ and $\left(c, c^{\prime}\right) \mathrm{Ni}_{25} / \mathrm{\gamma}_{\mathrm{\gamma}}-\mathrm{Al}_{2} \mathrm{O}_{3}$ over 10 or $20 \mathrm{~h}$ time on stream and $\mathrm{B}$. TEM micrograph of spent $\mathrm{Ni}_{15}-\mathrm{Al}_{2} \mathrm{O}_{3-\mathrm{MLL}-53}$ after $\mathrm{CO}_{2}$ methanation reaction. Conditions: $\mathrm{T}=350{ }^{\circ} \mathrm{C}, \mathrm{GHSV}=1435$ ml. ${ }^{-1} \cdot \min ^{-1}, \mathrm{H}_{2}: \mathrm{CO}_{2}=4: 1$. 
Fig. 10 displays the obtained rates as a function of the reaction temperature of different Ni/supportbased catalysts tested recently in literature in the $\mathrm{CO}_{2}$ methanation reaction. As a final step, a comparison between the best MIL-53-derived catalyst and other Ni/support-based catalysts tested recently in literature towards $\mathrm{CO}_{2}$ methanation reaction was intended. For this purpose, and taking into account that the conditions used in literature (e.g., mass of catalyst - W, inlet flow of $\mathrm{CO}_{2}-\mathrm{F}_{\mathrm{CO}}$,inlet) were not the same, average $\mathrm{CO}_{2}$ reaction rates (r) were determined far from the thermodynamic equilibrium and displayed in Fig. 10 as a function of the reaction temperature. From this comparison, our best performing catalyst that is $\mathrm{Ni}_{20}-\mathrm{Al}_{2} \mathrm{O}_{3-\mathrm{MIL}-53}$ is even better than $\mathrm{Ni}-\mathrm{Al}_{2} \mathrm{O}_{3}$ materials prepared by "layered double hydroxide" or "EISA" method (curves a,c, Fig.7). $\mathrm{Ni}_{20}-\mathrm{Al}_{2} \mathrm{O}_{3-\mathrm{MIL}-53}$ possesses also better average $\mathrm{CO}_{2}$ reaction rates than other $\mathrm{Ni}$-supported materials reported in literature (Fig. 7 curves b, c-l) with a wide range of support types ranging from sepiolite, zeolite FDU, mesoporous silica MCM-41, fibrous nanosphere silica KCC carbon nanotubes CNT, zirconia $\mathrm{ZrO}_{2}$, bentonite, metal oxide composites $\left(\mathrm{CeO}_{2}-\mathrm{ZrO}_{2}, \mathrm{Al}_{2} \mathrm{O}_{3}-\mathrm{ZrO}_{2}-\mathrm{TiO}_{2}-\mathrm{CeO}_{2}\right)$, and silicon carbide $\mathrm{SiC}$. This highlights on the superior performance of the new catalyst prepared in this study over the existed ones in literature. Finally, the same trend is even observed when comparing the average $\mathrm{CO}_{2}$ reaction rates calculated with Ni weight present in each catalyst (Fig. S4). The only difference concerns the sample supported on zirconia (curve g, Fig. S4) that displays better performances but which is however known to be more expensive than alumina.

The beneficial role of MIL-53 in the formation of catalysts with superior performances is mainly explained by the capacity of this hybrid framework to disperse the nickel precursors (nitrate salt) in close proximity to its $\mathrm{Al}\left(\mu_{2}-\mathrm{OH}\right)$ inorganic nodes [24]. This proximity of $\mathrm{Ni}^{2+}$ cations to octahedral coordinated trivalent $\mathrm{Al}^{3+}$ cations within the pores is assumed to favour the formation of nickel aluminate $\left(\mathrm{NiAl}_{2} \mathrm{O}_{4}\right)$ nanodomains, a spinel phase which is also composed of an ensemble of tetrahedral coordination occupied with bivalent $\mathrm{Ni}^{2+}$ and octahedral coordinated $\mathrm{Al}^{3+}$ cations [34]. The thermal removal of the organic linkers then results in the formation of inorganic materials with high surface areas (Table 1), in which the $\mathrm{NiAl}_{2} \mathrm{O}_{4}$ nanodomains are highly dispersed and close to the surface. We believe that forming such well-dispersed $\mathrm{NiAl}_{2} \mathrm{O}_{4}$ nanodomains is a key step towards particularly active and stable catalysts for several reasons: (i) the occurrence of the $\mathrm{Ni}^{2+}$ cations isolated within the $\mathrm{NiAl}_{2} \mathrm{O}_{3}$ nanodomains is believed to slow down their extraction from the support during the reduction step, thus contributing to the formation of well-dispersed tiny $\mathrm{Ni}^{0}$ nuclei that grow on the alumina surface at a limited extent to give small nanoparticles instead of few nuclei evolving as large metal particles, (ii) the occurrence of remaining nickel aluminate or related non stoichiometric nickel aluminate phases at the interface between the metal nanoparticle and alumina may improve the 
stability of these highly dispersed $\mathrm{Ni}^{0}$ nanoparticles by affording a particularly strong metal-support interaction, finally, (iii) this remaining $\mathrm{NiAl}_{2} \mathrm{O}_{4}$ is known to contain oxygen vacancies [49]. These species may therefore increase the $\mathrm{CO}_{2}$ adsorption and thereby the catalytic activity. Furthermore, the active oxygen species generated by filling the oxygen vacancies of $\mathrm{NiAl}_{2} \mathrm{O}_{4}$ spinel by $\mathrm{CO}_{2}$ may also provide a redox route to eliminate carbon species, responsible for the long-term stability and excellent resistance to coking and sintering of the MIL-53-derived catalysts in this study.

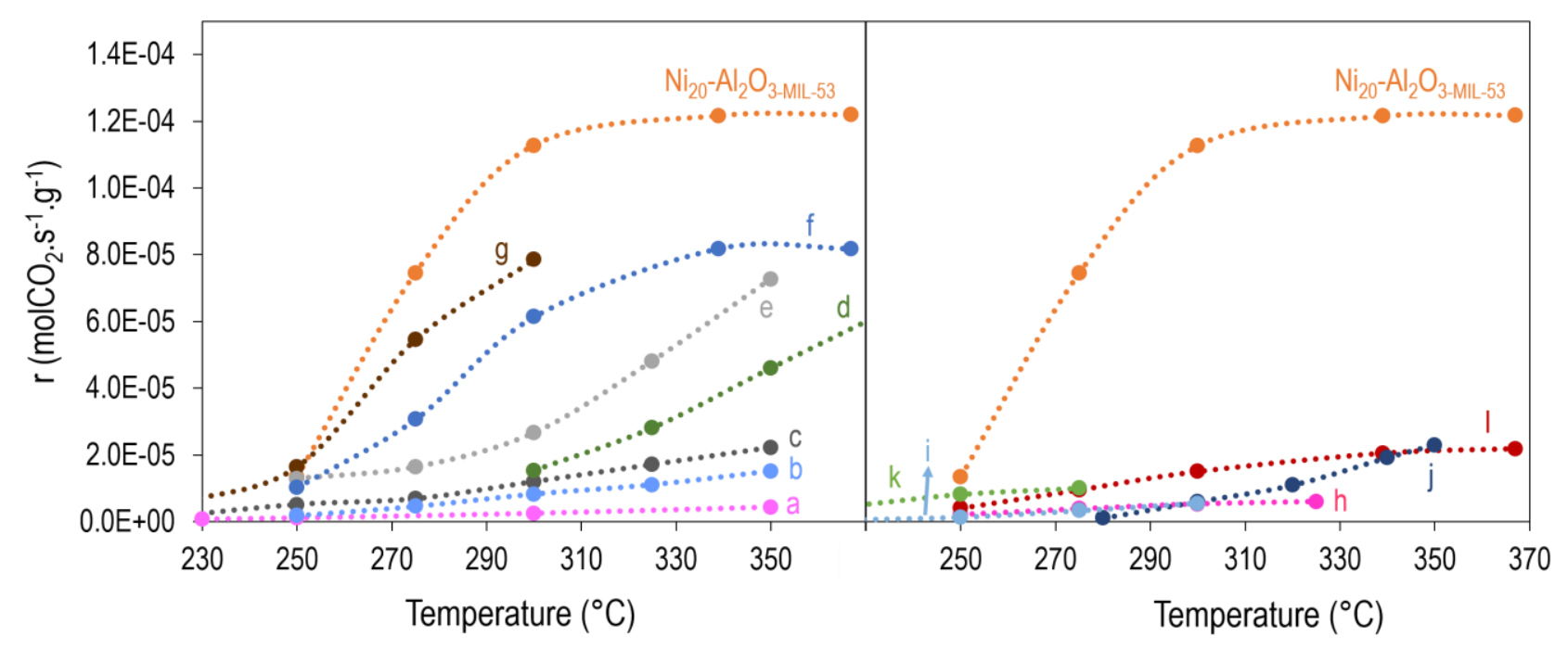

Figure 10: Comparison in the $230-370^{\circ} \mathrm{C}$ temperature range of the average $\mathrm{CO}_{2}$ reaction rates (in $\mathrm{mol}_{\mathrm{CO} 2.5}$ ${ }^{1} \cdot \mathrm{g}_{\text {cat }}{ }^{-1}$ ) on $\mathrm{Ni}_{20}-\mathrm{Al}_{2} \mathrm{O}_{3-\mathrm{ML}-53}$ (present work) and on catalysts of the literature detailed in Table $\mathrm{S1}: \mathrm{Ni}-\mathrm{Al}_{2} \mathrm{O}_{3}$ based catalysts $\mathrm{Ni}_{10}-\mathrm{Al}_{2} \mathrm{O}_{3}$ EISA and $\mathrm{Ni}_{2} / \mathrm{Al}_{2} \mathrm{O}_{3}$ (curves (a), (c)), other supported Ni-based catalysts (b) $\mathrm{Ni} / /$ Sepiolite, (d) $\mathrm{Ni} i_{10} / \mathrm{FDU}$, (e) $\mathrm{Ni}_{15} / \mathrm{MCM}-41$, (f) $\mathrm{Ni} i_{30} / \mathrm{CNT}$, (g) $\mathrm{Ni}_{9} / \mathrm{ZrO}_{2}$, (h) $\mathrm{Ni}_{16} / \mathrm{Al}_{2} \mathrm{O}_{3}-\mathrm{ZrO}_{2}-\mathrm{TiO}_{2}-\mathrm{CeO}_{2}$, (i)

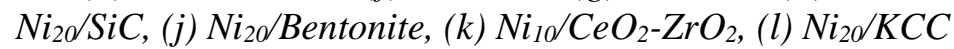

\section{Conclusion}

We described a novel approach for synthesizing active, selective and stable Ni-based alumina catalysts for $\mathrm{CO}_{2}$ methanation based on the use of MIL-53(Al) as a highly porous pre-support. The impregnation of nickel precursors within the pores of this MOF enabled the homogeneous dispersion of $\mathrm{Ni}^{2+}$ in close proximity with an alumina source. After calcination and subsequent $\mathrm{Ni}^{2+}$ reduction into $\mathrm{Ni}^{0}$, this strategy allowed the formation of well-dispersed and homogeneous $\mathrm{Ni}^{0}$ nanoparticles embedded within $\gamma-\mathrm{Al}_{2} \mathrm{O}_{3}$ interwoven nanosheets. Interestingly, employing MIL-53(Al) as pre-support allowed to obtain a remarkably well-dispersed and active $\mathrm{Ni}^{0}$ nanoparticles (size below $10 \mathrm{~nm}$ ) even with $\mathrm{Ni}$ amount as high as $20 \mathrm{wt} \%$. The performance of MIL-53(Al)-derived samples for the catalysis of the $\mathrm{CO}_{2}$ methanation was shown to be higher than those of more conventional Ni-based catalysts, such as $\mathrm{Ni}^{0}$ nanoparticles supported on $\gamma-\mathrm{Al}_{2} \mathrm{O}_{3}$ (a commercial catalyst from Evonik and a catalyst made by a onepot EISA procedure) as well as on silica (Ni samples supported over a USY zeolite and a SBA-15 
mesoporous silica). These better performances are mainly explained by the high dispersion of nickel nanoparticles within the MOF-derived catalysts and the formation after MOF calcination of nickel aluminate nanodomains that are presumed to play a positive role in the activity and stability of the catalyst. The best MOF-derived material (with $\mathrm{Ni}$ amount of $20 \mathrm{wt} \% ; \mathrm{Ni}_{20}-\mathrm{Al}_{2} \mathrm{O}_{3-\mathrm{MIL}-53}$ ) was also compared to other highly active methanation catalysts reported in literature. In all cases, MIL-53(Al)derived materials led to superior performances, both in terms of $\mathrm{CO}_{2}$ conversion and selectivity. Finally, these catalysts were shown to be remarkably stable even when submitted to time-on-stream as long as $20 \mathrm{~h}$.

\section{Acknowledgments}

The authors are grateful to the FP7 European program and related national organisms for SOL-CARE project funding (ERANETMED_ENERG-065, 2016-2019) and to the UOBRC for the BIRG 02/2016. M.C. Bacariza acknowledges Fundação para a Ciência e Tecnologia (FCT) for the financial support of the research group (UID/QUI/00100/2020). Sandra Casale (LRS, SU) is acknowledged for the recording of the electron microscopy images.

\section{References}

[1] H. Blanco, A. Faaij, A review at the role of storage in energy systems with a focus on Power to Gas and long-term storage, Renew. Sustain. Energy Rev. 81 (2018) 1049-1086. doi:10.1016/j.rser.2017.07.062.

[2] K. Ghaib, F.-Z. Ben-Fares, Power-to-Methane: A state-of-the-art review, Renew. Sustain. Energy Rev. 81 (2018) 433-446. doi:10.1016/j.rser.2017.08.004.

[3] J. Guilera, J. Ramon Morante, T. Andreu, Economic viability of SNG production from power and CO2, Energy Convers. Manag. 162 (2018) 218-224. doi:10.1016/j.enconman.2018.02.037.

[4] M. Sterner, Bioenergy and Renewable Power Methane In Integrated 100\% Renewable Energy Systems: Limiting Global Warming By Transforming Energy Systems, kassel university press GmbH, 2009.

[5] P. Denholm, E. Ela, B. Kirby, M. Milligan, The Role of energy storage with renewable electricity generation, Publ. (2010) 1-61.

[6] T. Schaaf, J. Grünig, M.R. Schuster, T. Rothenfluh, A. Orth, Methanation of CO2 - storage of renewable energy in a gas distribution system, Energy. Sustain. Soc. 4 (2014) 2. 
doi:10.1186/s13705-014-0029-1.

[7] C. Jia, J. Gao, Y. Dai, J. Zhang, Y. Yang, The thermodynamics analysis and experimental validation for complicated systems in CO2 hydrogenation process, J. Energy Chem. 25 (2016) 1027-1037. doi:10.1016/j.jechem.2016.10.003.

[8] W.J. Lee, C. Li, H. Prajitno, J. Yoo, J. Patel, Y. Yang, S. Lim, Recent trend in thermal catalytic low temperature CO2 methanation: A critical review, Catal. Today. (2020). doi:10.1016/j.cattod.2020.02.017.

[9] M. Younas, L. Loong Kong, M.J.K. Bashir, H. Nadeem, A. Shehzad, S. Sethupathi, Recent Advancements, Fundamental Challenges, and Opportunities in Catalytic Methanation of CO2, Energy and Fuels. 30 (2016) 8815-8831. doi:10.1021/acs.energyfuels.6b01723.

[10] C. Lv, L. Xu, M. Chen, Y. Cui, X. Wen, Y. Li, C.E. Wu, B. Yang, Z. Miao, X. Hu, Q. Shou, Recent Progresses in Constructing the Highly Efficient Ni Based Catalysts With Advanced Low-Temperature Activity Toward CO2 Methanation, Front. Chem. 8 (2020) 1-32. doi:10.3389/fchem.2020.00269.

[11] S. Tada, T. Shimizu, H. Kameyama, T. Haneda, R. Kikuchi, Ni/CeO2 catalysts with high CO2 methanation activity and high $\mathrm{CH} 4$ selectivity at low temperatures, Int. J. Hydrogen Energy. 37 (2012) 5527-5531. doi:10.1016/j.ijhydene.2011.12.122.

[12] P. Frontera, A. Macario, M. Ferraro, P. Antonucci, Supported Catalysts for CO2 Methanation: A Review, Catalysts. 7 (2017) 59. doi:10.3390/catal7020059.

[13] M. a. A. Aziz, A.A. Jalil, S. Triwahyono, A. Ahmad, CO2 methanation over heterogeneous catalysts: recent progress and future prospects, Green Chem. 17 (2015) 2647-2663. doi:10.1039/C5GC00119F.

[14] X. Su, J. Xu, B. Liang, H. Duan, B. Hou, Y. Huang, Catalytic carbon dioxide hydrogenation to methane: A review of recent studies, J. Energy Chem. 25 (2016) 553-565. doi:10.1016/j.jechem.2016.03.009.

[15] S. Saeidi, N.A.S. Amin, M.R. Rahimpour, Hydrogenation of CO2 to value-added products-A review and potential future developments, J. CO2 Util. 5 (2014) 66-81. doi:10.1016/j.jcou.2013.12.005.

[16] S. Rahmani, M. Rezaei, F. Meshkani, Preparation of promoted nickel catalysts supported on mesoporous nanocrystalline gamma alumina for carbon dioxide methanation reaction, J. Ind. Eng. Chem. 20 (2014) 4176-4182. doi:10.1016/j.jiec.2014.01.017. 
[17] Q. Liu, S. Wang, G. Zhao, H. Yang, M. Yuan, X. An, H. Zhou, Y. Qiao, Y. Tian, CO2 methanation over ordered mesoporous NiRu-doped $\mathrm{CaO}-\mathrm{Al} 2 \mathrm{O} 3$ nanocomposites with enhanced catalytic performance, Int. J. Hydrogen Energy. 43 (2018) 239-250. doi:10.1016/j.ijhydene.2017.11.052.

[18] J. Gao, Q. Liu, F. Gu, B. Liu, Z. Zhong, F. Su, Recent advances in methanation catalysts for the production of synthetic natural gas, RSC Adv. 5 (2015) 22759-22776. doi:10.1039/c4ra16114a.

[19] L. Karam, M. Armandi, S. Casale, V. El Khoury, B. Bonelli, P. Massiani, N. El Hassan, Comprehensive study on the effect of magnesium loading over nickel-ordered mesoporous alumina for dry reforming of methane, Energy Convers. Manag. 225 (2020) 113470. doi:10.1016/j.enconman.2020.113470.

[20] L. Karam, M.C. Bacariza, J.M. Lopes, C. Henriques, P. Massiani, N. El Hassan, Assessing the potential of xNi-yMg-A12O3 catalysts prepared by EISA-one-pot synthesis towards $\mathrm{CO} 2$ methanation: An overall study, Int. J. Hydrogen Energy. 45 (2020) 28626-28639. doi:10.1016/j.ijhydene.2020.07.170.

[21] M. Ding, R.W. Flaig, H.L. Jiang, O.M. Yaghi, Carbon capture and conversion using metalorganic frameworks and MOF-based materials, Chem. Soc. Rev. 48 (2019) 2783-2828. doi:10.1039/c8cs00829a.

[22] R. Lippi, S.C. Howard, H. Barron, C.D. Easton, I.C. Madsen, L.J. Waddington, C. Vogt, M.R. Hill, C.J. Sumby, C.J. Doonan, D.F. Kennedy, Highly active catalyst for CO2 methanation derived from a metal organic framework template, J. Mater. Chem. A. 5 (2017) 12990-12997. doi:10.1039/C7TA00958E.

[23] W. Li, A. Zhang, X. Jiang, C. Chen, Z. Liu, C. Song, X. Guo, Low Temperature CO2 Methanation: ZIF-67-Derived Co-Based Porous Carbon Catalysts with Controlled Crystal Morphology and Size, Acs Sustain. Chem. Eng. 5 (2017) 7824-7831. doi:10.1021/acssuschemeng.7b01306.

[24] L. Karam, J. Reboul, S. Casale, N. El Hassan, P. Massiani, Porous nickel-alumina derived from metal-organic framework (MIL-53): a new approach to achieve active and stable catalysts in methane dry reforming, ChemCatChem. 12 (2019) 373-385.

[25] L. Karam, J. Reboul, N. El Hassan, J. Nelayah, P. Massiani, Nanostructured nickel aluminate as a key intermediate for the production of highly dispersed and stable nickel nanoparticles 
supported within mesoporous alumina for dry reforming of methane, Molecules. 24 (2019) 4107-4120. doi:10.3390/molecules24224107.

[26] V.I. Isaeva, A.L. Tarasov, V. V. Chernyshev, L.M. Kustov, Control of morphology and size of microporous framework MIL-53(Al) crystals by synthesis procedure, Mendeleev Commun. 25 (2015) 466-467. doi:10.1016/j.mencom.2015.11.023.

[27] M.C. Bacariza, I. Graça, J.M. Lopes, C. Henriques, Enhanced activity of CO2 hydrogenation to $\mathrm{CH} 4$ over $\mathrm{Ni}$ based zeolites through the optimization of the $\mathrm{Si} / \mathrm{Al}$ ratio, Microporous Mesoporous Mater. 267 (2018) 9-19. doi:10.1016/j.micromeso.2018.03.010.

[28] M.C. Bacariza, I. Graça, J.M. Lopes, C. Henriques, Ni-Ce/Zeolites for CO2 Hydrogenation to CH4: Effect of the Metal Incorporation Order, ChemCatChem. 10 (2018) 2773-2781. doi:10.1002/cctc.201800204.

[29] L. Karam, N. El Hassan, Advantages of mesoporous silica based catalysts in methane reforming by CO 2 from kinetic perspective, J. Environ. Chem. Eng. 6 (2018) 4289-4297. doi:10.1016/j.jece.2018.06.031.

[30] M.W. Anderson, J. Klinowski, Zeolites treated with silicon tetrachloride vapour. Part 1.Preparation and characterisation, J. Chem. Soc. Faraday Trans. 1 Phys. Chem. Condens. Phases. 82 (1986) 1449-1469. doi:10.1039/F19868201449.

[31] T. Remy, S.A. Peter, L. Van Tendeloo, S. Van der Perre, Y. Lorgouilloux, C.E.A. Kirschhock, J.A. Martens, Y. Xiong, G. V. Baron, J.F.M. Denayer, Adsorption and separation of CO2 on KFI zeolites: effect of cation type and $\mathrm{Si} / \mathrm{Al}$ ratio on equilibrium and kinetic properties, Langmuir ACS J. Surfaces Colloids. 29 (2013) 4998-5012. doi:10.1021/la400352r.

[32] M.C. Bacariza, M. Maleval, I. Graça, J.M. Lopes, C. Henriques, Power-to-methane over Ni/zeolites: Influence of the framework type, Microporous Mesoporous Mater. 274 (2019) 102-112. doi:10.1016/j.micromeso.2018.07.037.

[33] W.J. Jang, H.M. Kim, J.O. Shim, S.Y. Yoo, K.W. Jeon, H.S. Na, Y.L. Lee, D.W. Jeong, J.W. Bae, I.W. Nah, H.S. Roh, Key properties of Ni-MgO-CeO2, Ni-MgO-ZrO2, and Ni-MgO$\mathrm{Ce}(1-\mathrm{x}) \mathrm{Zr}(\mathrm{x}) \mathrm{O} 2$ catalysts for the reforming of methane with carbon dioxide, Green Chem. 20 (2018) 1621-1633. doi:10.1039/c7gc03605a.

[34] M.K. Nazemi, S. Sheibani, F. Rashchi, V.M. Gonzalez-Delacruz, A. Caballero, Preparation of nanostructured nickel aluminate spinel powder from spent $\mathrm{NiO} / \mathrm{Al} 2 \mathrm{O} 3$ catalyst by mechanochemical synthesis, Adv. Powder Technol. 23 (2012) 833-838. doi:10.1016/j.apt.2011.11.004. 
[35] M. Shah, S. Das, A.K. Nayak, P. Mondal, A. Bordoloi, Smart designing of metal-support interface for imperishable dry reforming catalyst, Appl. Catal. A Gen. 556 (2018) 137-154. doi:10.1016/j.apcata.2018.01.007.

[36] C.M. Mfoumou, S. Mignard, T. Belin, The preferential adsorption sites of $\mathrm{H} 2 \mathrm{O}$ on adsorption sites of CO2 at low temperature onto $\mathrm{NaX}$ and BaX zeolites, Adsorpt. Sci. Technol. (2018) 114. doi:10.1177/0263617418762494.

[37] M.C. Bacariza, M. Biset-Peiró, I. Graça, J. Guilera, J. Morante, J.M. Lopes, T. Andreu, C. Henriques, DBD plasma-assisted CO2 methanation using zeolite-based catalysts: Structure composition-reactivity approach and effect of Ce as promoter, J. CO2 Util. 26 (2018) 202211. doi:10.1016/j.jcou.2018.05.013.

[38] A. Cárdenas-Arenas, A. Quindimil, A. Davó-Quiñonero, E. Bailón-García, D. LozanoCastelló, U. De-La-Torre, B. Pereda-Ayo, J.A. González-Marcos, J.R. González-Velasco, A. Bueno-López, Isotopic and in situ DRIFTS study of the CO2 methanation mechanism using $\mathrm{Ni} / \mathrm{CeO} 2$ and Ni/A12O3 catalysts, Appl. Catal. B Environ. 265 (2020). doi:10.1016/j.apcatb.2019.118538.

[39] A. Westermann, B. Azambre, M.C. Bacariza, I. Graça, M.F. Ribeiro, J.M. Lopes, C. Henriques, Insight into CO2 methanation mechanism over NiUSY zeolites: An operando IR study, Appl. Catal. B Environ. 174-175 (2015) 120-125. doi:10.1016/j.apcatb.2015.02.026.

[40] A. Lechkar, A. Barroso Bogeat, G. Blanco, J.M. Pintado, M. Soussi el Begrani, Methanation of carbon dioxide over ceria-praseodymia promoted $\mathrm{Ni}$-alumina catalysts. Influence of metal loading, promoter composition and alumina modifier, Fuel. 234 (2018) 1401-1413. doi:10.1016/j.fuel.2018.07.157.

[41] L. Karam, S. Casale, H. El Zakhem, N. El Hassan, Tuning the properties of nickel nanoparticles inside SBA-15 mesopores for enhanced stability in methane reforming, J. CO2 Util. 17 (2017) 119-124. doi:10.1016/j.jcou.2016.12.002.

[42] I. Graça, L. V. González, M.C. Bacariza, A. Fernandes, C. Henriques, J.M. Lopes, M.F. Ribeiro, CO2 hydrogenation into CH4 on NiHNaUSY zeolites, Appl. Catal. B Environ. 147 (2014) 101-110. doi:10.1016/j.apcatb.2013.08.010.

[43] J.H. Park, S. Yeo, T.S. Chang, Effect of supports on the performance of Co-based catalysts in methane dry reforming, J. CO2 Util. 26 (2018) 465-475. doi:10.1016/j.jcou.2018.06.002.

[44] W. Zhen, B. Li, G. Lu, J. Ma, Enhancing catalytic activity and stability for CO2 methanation 
on Ni@MOF-5 via control of active species dispersion, Chem. Commun. 51 (2015) 17281731. doi:10.1039/C4CC08733J.

[45] A. Cárdenas-Arenas, A. Quindimil, A. Davó-Quiñonero, E. Bailón-García, D. LozanoCastelló, U. De-La-Torre, B. Pereda-Ayo, J.A. González-Marcos, J.R. González-Velasco, A. Bueno-López, Isotopic and in situ DRIFTS study of the CO2 methanation mechanism using Ni/CeO2 and Ni/Al2O3 catalysts, Appl. Catal. B Environ. 265 (2020) 118538. doi:10.1016/j.apcatb.2019.118538.

[46] J. Yang Lim, J. McGregor, A.J. Sederman, J.S. Dennis, Kinetic studies of CO2 methanation over a Ni/ $\gamma$-Al2O3 catalyst using a batch reactor, Chem. Eng. Sci. 141 (2016) 28-45. doi:10.1016/j.ces.2015.10.026.

[47] C. Vogt, M. Monai, E.B. Sterk, J. Palle, A.E.M. Melcherts, B. Zijlstra, E. Groeneveld, P.H. Berben, J.M. Boereboom, E.J.M. Hensen, F. Meirer, I.A.W. Filot, B.M. Weckhuysen, Understanding carbon dioxide activation and carbon-carbon coupling over nickel, Nat. Commun. 10 (2019) 1-10. doi:10.1038/s41467-019-12858-3.

[48] M.C. Bacariza, I. Graça, S.S. Bebiano, J.M. Lopes, C. Henriques, Micro- and mesoporous supports for CO2 methanation catalysts: A comparison between SBA-15, MCM-41 and USY zeolite, Chem. Eng. Sci. 175 (2018) 72-83. doi:10.1016/j.ces.2017.09.027.

[49] S. Zhang, M. Ying, J. Yu, W. Zhan, L. Wang, Y. Guo, Y. Guo, NixAl1O2- $\delta$ mesoporous catalysts for dry reforming of methane: The special role of NiAl2O4 spinel phase and its reaction mechanism, Appl. Catal. B Environ. 291 (2021) 120074. doi:10.1016/j.apcatb.2021.120074. 